\title{
SLAG COMPOUNDS FORMED FROM THE NODULARIZATION TREATMENT UNTIL POURING THE MOLDS TO PRODUCE SPHEROIDAL GRAPHITE CAST IRON PARTS
}

\section{Introduction}

1 The present work is included as part of a research undertaken about the effect of raw materials and some processing variables on the origin and the composition of those slag compounds formed along the manufacture of spheroidal graphite cast iron parts. In this second part, the composition and phases present in an important number of slag samples obtained from Mg-treated melts from the nodularizing treatment until pouring the molds have been investigated and discussed. Both slag samples which are floating in the melts surface and those adhered to the refractory lining of the pouring device have been analyzed. Finally, two different morphologies of slag inclusions found on cast iron parts have been studied and then compared to the results obtained from the previous slag samples characterization. It has been observed that composition of slag varies along the different steps of the production process as a function of the oxidizing level of the gas which is in contact with the melts and also of the remaining time in the ladle. Regarding crystallinity of slag, it has been found that it strongly depends on its composition and formation rate. All the information obtained from the study of slag formed before pouring process has been then used for estimating the origin of the slag inclusions commonly found in manufactured cast parts.

Keywords: spheroidal graphite cast irons, slag compounds, $X$-ray diffraction, X-ray fluorescence, scanning electron microscopy, slag inclusions, dross inclusions

are approached so as to determine their origin, consequences and the affecting factors.

Some authors ${ }^{1}$ who have studied the slag products collected from melts already treated with magnesium alloys have concluded that the amount of formed slag increases when reducing the temperature of liquid alloys. Thus they recommended the use of high pouring temperatures and low pouring times in order to minimize chemical interactions between the liquid alloy and the air, and proper designed filling systems to reduce turbulences when filling the molds. Another recommendation reported by these authors was to minimize the period of time usually needed from the end of the Mg-treatment until pouring the molds.

Slag compounds formed during the Mg-treatment can also negatively affect refractory linings according to their viscosity and adherence. Additionally, the formation of this 


\begin{tabular}{|l|lll|}
\hline Journal : Large 40962 & Dispatch : 9-2-2016 & Pages : 17 \\
& Article No. : 26 & $\square$ LE & $\square$ TYPESET \\
MS Code : IJMC-D-15-00004 & $\square_{\text {CP }}$ & $\checkmark$ DSK \\
\hline
\end{tabular}

80 kind of slag becomes continuous after the end of $\mathrm{Mg}$ treatments as magnesium oxides, sulfides and silicates can be generated, while free magnesium is still present in melts. On the other hand, the composition and the amount of these slag compounds can change as a function of the FeSiMg alloy used. Thus, it has been found that those ferroalloys with a comparatively low magnesium content led to less amount of slag in the melt surfaces, while the presence of specific elements as barium in the ferroalloy increases the degradation of refractory linings. ${ }^{2}$

Regarding the slag compounds found as inclusions in manufactured parts, it has been reported ${ }^{3}$ that their morphology can be classified as large particles, small particles and stringers. The X-ray diffraction analysis of large particles shows that they are mainly composed by forsterite $\left(\mathrm{Mg}_{2} \mathrm{SiO}_{4}\right)$. The same authors also analyzed slag samples extracted from the melt that remains in the Mg-treatment ladle and observed variable amounts of forsterite $\left(\mathrm{Mg}_{2} \mathrm{SiO}_{4}\right)$, fayalite $\left(\mathrm{Fe}_{2} \mathrm{SiO}_{4}\right)$, enstatite $\left(\mathrm{MgSiO}_{3}\right), \mathrm{Fe}-$ bearing compounds, alumina $\left(\mathrm{Al}_{2} \mathrm{O}_{3}\right)$ and $\mathrm{MgS}$ depending on the characteristics of the manufacturing process used. It has been accounted that the formation of these slag products starts by means of an oxidation of the magnesium and silicon followed by a subsequent reaction between these oxides and other compounds in order to form the final products already mentioned ${ }^{4}$. Other studies ${ }^{5}$ also corroborate that the most important phases detected in slag inclusions found in SG castings are composed by silicates of aluminum, calcium and magnesium and oxides of aluminum and magnesium.

Regarding those inclusions found in parts with a filamentary and elongated contour and normally surrounded by degenerated graphite particles, again their composition has been found to mainly be $\mathrm{MgSiO}_{3}$ and $\mathrm{Mg}_{2} \mathrm{SiO}_{4}$. Such slag inclusions are commonly known as "dross inclusions," and they can be normally detected in internal areas of mediumand heavy-section castings. Dross formation is promoted by the oxygen exposure of melts, i.e., high turbulences, low pouring temperatures and high magnesium and silicon contents. Relevant differences on dross composition can also be found according to these promoting factors. ${ }^{6,7}$ In a more recent study ${ }^{8}$ focused on predicting dross formation in the production of SG cast iron castings, it is shown that the composition of these inclusions becomes complex, but is basically composed by $\mathrm{SiO}_{2}$ and $\mathrm{MgO}$ as main constituents. However, a detailed study of the phases present in the defect is not available in this study.

Dross can be detected in SG parts produced even after removing properly the slag present in the melt before pouring the molds. This fact is also a consequence of the continuous oxidation of silicon and magnesium in the liquid iron before the solidification step. Thus, these two elements progressively oxidize and then react with other compounds to originate small inclusions in local areas of melts that remain in the liquid state or when solidifying. The elongated shapes frequently found in dross inclusions seem to be the result of local flows in the liquid and/or in the semisolid media. An important consequence of these inclusions is the dramatic reduction of the mechanical properties of the cast iron.

The present work shows the results obtained in the second part of this investigation about slag compounds generated in the SG cast iron production. Accordingly, the structural phases and the composition of slags generated during $\mathrm{Mg}$ treatments and during pouring processes have been investigated and their origin discussed. Finally, the obtained results have been also compared to the characteristics of slag inclusions found in different castings manufactured according to the production process approached in the present work.

\section{Experimental Part}

The base melts were prepared in a 6-t capacity medium frequency induction furnace $(250 \mathrm{~Hz}, 4250 \mathrm{~kW})$ using the standard metallic charge used in the foundry plant (see Table 1). Raw materials are introduced in the furnace crucible when a remaining amount of melt (around $4000 \mathrm{~kg}$ ) is still in it. After melting step, the chemical composition of melts was adjusted (Table 2) by adding the needed amounts of graphite and/or FeSi (75.2 wt $\% \mathrm{Si}$, $0.7 \mathrm{wt} \% \mathrm{Al}$ and $0.3 \mathrm{wt} \% \mathrm{Ca}$ ). Then the temperature is increased up to the final value, and around $2000 \mathrm{~kg}$ of the base alloys was transferred to a ladle for treating them with a FeSiMg alloy by means of the sandwich method using steel scrap as covering material.

In a first step, five slag samples were obtained from different batches, each of them composed by around $2000 \mathrm{~kg}$ of Mg-treated cast iron that remain in the ladle. Sampling was done before using any deslagging product to remove the formed slag. These samples are composed by solid slag and were floating in the melt surface as scabs just after finishing the Mg-treatments. The amount of FeSiMg used for preparing each treated batch and the temperature of the melt when sampling is shown in Table 3. Notice that two different temperatures and three different FeSiMg additions were used in this group of experiments. All these slag samples have been identified as slag ladle treatment (SLT) accompanied by the sample number.

Table 1. Metallic Charge Composition Used in the Induction Furnace (wt\%)

\begin{tabular}{lllll}
\hline Pig iron & Steel scrap & Returns & Graphite $^{\mathrm{a}}$ & $\mathrm{SiC}^{\mathrm{b}}$ \\
\hline 2.5 & 37 & 59 & 1.4 & 1.0
\end{tabular}

a Carbon content: $99.9 \mathrm{wt} \%$

b SiC composition: 65 wt $\% \mathrm{Si}, 25$ wt $\% \mathrm{C}$ and $0.8 \mathrm{wt} \% \mathrm{Al}$
151 


\begin{tabular}{|l|lll|}
\hline Journal : Large 40962 & Dispatch : 9-2-2016 & Pages : 17 \\
& Article No. : 26 & $\square$ LE & $\square$ TYPESET \\
MS Code : IJMC-D-15-00004 & $\square_{\text {CP }}$ & $\checkmark$ DSK \\
\hline
\end{tabular}

Table 2. Chemical Composition Ranges of the Base Melts Prepared in the Present Work (wt\%)

\begin{tabular}{lllllllll}
\hline $\mathrm{C}$ & $\mathrm{Mn}$ & $\mathrm{Si}$ & $\mathrm{S}$ & $\mathrm{Mg}$ & $\mathrm{Al}$ & $\mathrm{Ti}$ & $\mathrm{Ce}$ & $\mathrm{Zn}$ \\
\hline $3.70-3.90$ & $0.20-0.35$ & $2.10-2.40$ & $<0.015$ & $<0.005$ & $<0.010$ & $<0.030$ & $<0.005$ & $<0.200$ \\
\hline
\end{tabular}

Table 3. Melt Temperatures After the Mg-Treatments and FeSiMg Additions Used

\begin{tabular}{lll}
\hline Sample & $\mathrm{FeSiMg}^{\mathrm{a}} / \mathrm{kg}$ & $T{ }^{\circ} \mathrm{C}\left({ }^{\circ} \mathrm{F}\right)$ \\
\hline SLT-1 & 12 & $1545(2813)$ \\
SLT-2 & 15 & $1545(2813)$ \\
SLT-3 & 15 & $1545(2813)$ \\
SLT-4 & 13 & $1500(2732)$ \\
SLT-5 & 15 & $1500(2732)$ \\
\hline
\end{tabular}

${ }^{a}$ FeSiMg composition: 45.4 wt $\%$ Si, 9.2 wt $\%$ Mg, 3.0 wt $\%$ Ca, $0.4 \mathrm{wt} \% \mathrm{Al}$ and $2.9 \mathrm{wt} \%$ rare earth elements
In a second group of experiments, four slag samples were progressively obtained from the surface of the melt contained in the ladle after finishing the $\mathrm{Mg}$-treatment. In order to prepare this particular batch, $2000 \mathrm{~kg}$ of the base alloy was transferred from the melting furnace to the ladle in which $12 \mathrm{~kg} \mathrm{FeSiMg}$ and $18 \mathrm{~kg}$ steel scrap (this last as covering material) were previously added. As before the Mg-treatment procedure used was the sandwich method. The goal of this second set of samples is to detect any potential change of slag composition regarding the amount of the existing crystalline phases or concerning the formation of new ones. Table 4 shows the melt temperature values and the different periods of time during sampling. These samples have been identified as slag ladle (SL) followed by the sample number. After each sampling process, the melt surface was properly skimmed in order to facilitate the formation of new slag compounds. Together with all these slag samples obtained at the time steps indicated in Table 4, melt samples were also taken so as to determine the evolution of the chemical composition of the alloy.

The third set of experiments is focused on the characterization of slag compounds formed in the pouring device. Once Mg-treatments were finished, melts were introduced in a pouring unit with pressurized nitrogen and with a

Table 4. Melt Temperature Evolution During the Progressive Sampling of a Mg-Treated Batch

\begin{tabular}{llc}
\hline Sample & $T /{ }^{\circ} \mathrm{C}\left({ }^{\circ} \mathrm{F}\right)$ & $t / \mathrm{min}$ \\
\hline $\mathrm{SL}-1$ & $1452(2646)$ & 0 \\
SL-2 & $1408(2566)$ & 10 \\
SL-3 & $1363(2485)$ & 21 \\
SL-4 & $1333(2431)$ & 30 \\
\hline
\end{tabular}

heater system. This kind of slag compounds becomes critical as it is formed during the last step before filling the molds. Thus, three different slag samples were obtained from the pouring basin area (close to the stopper) when the melt temperature was in the range $1390-1400{ }^{\circ} \mathrm{C}$ $\left(2534-2552^{\circ} \mathrm{F}\right)$. These samples were collected at intervals of $2 \mathrm{~h}$, and they have been identified by SPF notation (slag pressure pour furnace) followed by the sample number.

The next group of samples considered in the present work is composed by four slag samples. All of them were adhered to different zones of the alumina refractory lining which is present in the internal surfaces of the pressure pour furnace. In Figure 1 is shown a schematic view of the samples extraction zone. These samples were referenced as slag adhered to the inductor channel (SIC), slag adhered to the refractory walls present in the pressurized cavity (SIW), slag adhered to the recharge spout (SRS) and finally slag adhered to pouring basin (SPB).

In the last group of samples studied, two different slag inclusions found in SG cast iron parts have been approached so as to complete a whole set of slag samples that can be formed from melts after treating them with FeSiMg. It seems to be relevant to emphasize here that all the samples analyzed in the present work were obtained under the regular manufacturing conditions used to produce smalland medium-section SG cast iron parts in the foundry plant where all the experimental work was done.

Chemical composition of cast iron alloys was determined by analyzing melt samples that were also picked up during all slag sampling procedures. These analyses were performed using a combustion technique (LECO CS200) for carbon and sulfur and spark emission spectroscopy (ARL Metal Analyzer Iron + Steel) for the rest of elements.

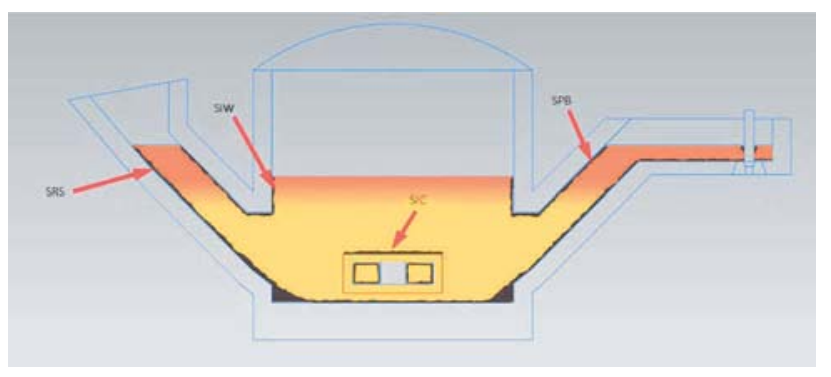

Figure 1. Schematic view of the extraction zone of the samples adhered to the refractory lining of the pouring furnace. 


\begin{tabular}{|l|lll|}
\hline Journal : Large 40962 & Dispatch : 9-2-2016 & Pages : 17 \\
& Article No. : 26 & $\square$ LE & $\square$ TYPESET \\
MS Code : IJMC-D-15-00004 & $\square_{\text {CP }}$ & $\checkmark$ DSK \\
\hline
\end{tabular}

Three different analytical techniques, i.e., X-ray diffraction (XRD), X-ray fluorescence (XRF) and scanning electron microscopy (SEM) with energy-dispersive X-ray spectroscopy (EDS) microanalysis, were used for characterizing all the slag samples collected in the present part of the investigation. The first technique was used to determine chemical compositions of slag samples. Thus, samples were crushed in an agate mortar and then were burned at $950{ }^{\circ} \mathrm{C}\left(1742{ }^{\circ} \mathrm{F}\right)$ for $24 \mathrm{~h}$ to remove any remaining amount of carbon and/or sulfur. Then $0.15 \mathrm{~g}$ of calcined sample was mixed with $5.7 \mathrm{~g}$ lithium tetraborate and $5 \mathrm{mg}$ lithium iodide as surfactant agent was finally added to the mixture. The resulting mixture was then melted at $1100{ }^{\circ} \mathrm{C}$ $\left(2012{ }^{\circ} \mathrm{F}\right)$ in an induction furnace (Perle' X-3) to obtain $30 \mathrm{~mm}$ (1.18 in.) in diameter pearls for subsequent XRF analysis. The fluorescence intensity was measured by means of a AXIOS Advanced wavelength dispersion X-ray sequential spectrophotometer equipped with a semiquantitative software program for elements with atomic number higher than $9(\mathrm{~F})$, using as excitation source a tube with a $\mathrm{Rh}$ anode. The quantification of the elements is done using a calibration line previously made using international reference geological samples whose composition was also determined by XRF.

XRD was used to characterize those structural phases present on each slag sample. These analyses were made by means of a PANalytical X'Pert PRO MPD q/q BraggBrentano powder diffractometer $240 \mathrm{~mm}$ (9.45 in.) in radius. The slag samples were previously crushed in an agate mortar until micrometer size. Then these samples were placed in a rectangular standard holder $20 \mathrm{~mm}$ (0.79 in.) in length, $15 \mathrm{~mm}$ (0.59 in.) in width and $1 \mathrm{~mm}$ (0.04 in.) in height in order to obtain a flat surface by manual pressing of the powder material using a glass plate. Finally, SEM-EDS microanalysis was used to corroborate the results obtained from the two other techniques and to check the slag samples microstructure. For this purpose, the samples were broken in small pieces and then were embedded in epoxy resin at room temperature. After conditioning the embedded samples for metallographic inspection, they were sputtered with carbon and then analyzed using a ESEM Quanta 200 FEI, XTE 325/D8395 apparatus with observation conditions of $\mathrm{AV}=20.00 \mathrm{kV}$, $\mathrm{WD}=10 \mathrm{~mm}$ (0.39 in.) and intensity probe of $4.5 \mathrm{nA}$. Secondary electron mode (SE image) and backscattered electron mode (BSE image) were also used for characterizing the slag samples.

\section{Results and Discussion}

\section{Slag Compounds Generated from Mg-Treated Melts Contained in the Ladle}

Slag formed in the ladle after finishing the Mg-treatments is normally found as scabs that are floating in the melt surface. Once extracted from the melt and then cooled at room temperature, these slag compounds show an apparent vitreous morphology and they are dark gray colored. Chemical compositions of the batches where sampling process was done are shown in Table 5.

After comparing data included in Tables 3 and 5, it is noted that the highest $\mathrm{Mg}$ and $\mathrm{Ce}$ contents are obtained in those melts prepared using the highest $\mathrm{FeSiMg}$ addition $(15 \mathrm{~kg})$ and the lowest temperature. As expected, both conditions are favorable to obtain the highest $\mathrm{Mg}$ and $\mathrm{Ce}$ yields after nodularization step. On the contrary, the lowest $\mathrm{Mg}$ and $\mathrm{Ce}$ contents are obtained in those melts prepared using the lowest FeSiMg addition (12 kg) and the highest temperature.

The results obtained from the XRF analyses performed on the five slag samples collected are included in Table 6.

The results included in Table 6 indicate that silicon oxide is the main constituent of all SLT samples as silicon is the main alloying element and it shows a high propensity to be oxidized. This fact was already observed on slag samples collected from base melts that were prepared using induction furnaces (Ref. part I) though the amounts of $\mathrm{SiO}_{2}$ were slightly higher in those samples than in STL ones. Notice that the silicon contents are even higher for the Mgtreated melts (Table 5) than for the base melts (Ref. part I). In case of the other easily oxidizable elements (aluminum, calcium and magnesium), the content of their oxides is significantly higher in the STL samples than in slag compounds found in the induction furnaces (Ref. part I) apart from aluminum case for those base melts prepared using steel scrap as main constituent of metallic charges. This fact is due to the addition of these three elements by means of the FeSiMg used in the nodularization process. Regarding cerium, this element is also included in the composition of the FeSiMg alloy and the $\mathrm{CeO}_{2}$ oxide is thus detected on most STL samples (Table 6). This oxide was only detected for those base melts fabricated using ductile iron returns as main raw material of the melting charges (Ref. part I).

The XRD analyses carried out on the STL samples show that they are composed by amounts of amorphous phases which are lower than the ones found on the slag samples collected from the surfaces of base melts that remained in induction furnaces (Ref. part I). The main crystalline phases found on STL samples are quartz $\left(\mathrm{SiO}_{2}\right)$, spinel $\left(\mathrm{MgAl}_{2} \mathrm{O}_{4}\right)$ and forsterite $\left\{(\mathrm{Mg}, \mathrm{Fe})_{2} \mathrm{SiO}_{4}\right\}$. The amount of these phases depends on the $\mathrm{SiO}_{2}, \mathrm{MgO}$ and $\mathrm{Al}_{2} \mathrm{O}_{3}$ contents that are present in each STL sample. For example, the highest levels of aluminum and magnesium oxides have been detected on the SLT-4 sample (Table 6) and therefore it shows both spinel and forsterite as the main crystalline phases. Other minor phases are cristobalite $\left(\mathrm{SiO}_{2}\right)$, moissanite $(\mathrm{SiC})$, iron silicide $\left(\mathrm{Fe}_{3} \mathrm{Si}\right)$, hematite $\left(\mathrm{Fe}_{2} \mathrm{O}_{3}\right)$ and calcium sulfide $(\mathrm{CaS})$. In all the STL samples, the 


\begin{tabular}{|l|lll|}
\hline Journal : Large 40962 & Dispatch : 9-2-2016 & Pages : 17 \\
& Article No. : 26 & $\square$ LE & $\square$ TYPESET \\
MS Code : IJMC-D-15-00004 & $\square_{\text {CP }}$ & $\checkmark$ DSK \\
\hline
\end{tabular}

Table 5. Chemical Compositions of the Mg-Treated Melts During Sampling Process (wt\%)

\begin{tabular}{llllllllll}
\hline Sample & $\mathrm{C}$ & $\mathrm{Mn}$ & $\mathrm{Si}$ & $\mathrm{S}$ & $\mathrm{Mg}$ & $\mathrm{Al}$ & $\mathrm{Ti}$ & $\mathrm{Ce}$ & $\mathrm{Zn}$ \\
\hline SLT-1 & 3.79 & 0.34 & 2.44 & 0.011 & 0.039 & 0.006 & 0.019 & 0.009 & 0.169 \\
SLT-2 & 3.74 & 0.34 & 2.61 & 0.013 & 0.046 & 0.007 & 0.022 & 0.011 & 0.157 \\
SLT-3 & 3.74 & 0.33 & 2.44 & 0.009 & 0.045 & 0.006 & 0.023 & 0.011 & 0.150 \\
SLT-4 & 3.71 & 0.31 & 2.49 & 0.008 & 0.049 & 0.006 & 0.026 & 0.011 & 0.171 \\
SLT-5 & 3.73 & 0.32 & 2.70 & 0.008 & 0.064 & 0.006 & 0.024 & 0.013 & 0.175 \\
\hline
\end{tabular}

Table 6. Chemical Composition of Floating Slag Samples Collected from the Five Recent Mg-Treated Melts (wt\%)

\begin{tabular}{llllllrrr}
\hline Sample & $\mathrm{SiO}_{2}$ & $\mathrm{Al}_{2} \mathrm{O}_{3}$ & $\mathrm{CaO}$ & $\mathrm{MgO}$ & $\mathrm{Fe}_{2} \mathrm{O}_{3}$ & $\mathrm{SO}_{3}$ & $\mathrm{CeO}_{2}$ & $\mathrm{MnO}^{2}$ \\
\hline SLT-1 & 54.10 & 14.34 & 11.65 & 10.49 & 2.98 & 1.14 & 1.12 & $<1.00$ \\
SLT-2 & 44.39 & 17.26 & 15.97 & 14.75 & 2.50 & 1.13 & 1.55 & $<1.00$ \\
SLT-3 & 58.73 & 15.59 & 8.33 & 9.69 & 2.78 & $<1.00$ & 1.11 & 1.17 \\
SLT-4 & 36.58 & 22.94 & 16.93 & 17.36 & 1.53 & $<1.00$ & 1.71 & $<1.00$ \\
SLT-5 & 68.06 & 10.38 & 7.31 & 6.75 & 2.81 & $<1.00$ & $<1.00$ & $<1.00$ \\
\hline
\end{tabular}

preferential allotropic form of $\mathrm{SiO}_{2}$ is quartz. This observation could be explained due to the lack of time for the quartz-cristobalite allotropic transformation in the interval from the formation of the slag compound and its extraction. The SEM micrograph of the SLT-1 slag sample is shown in Figure 2a where dark particles of expected spinel $\left(\mathrm{MgAl}_{2} \mathrm{O}_{4}\right)$ surrounded by an amorphous mass of oxides can be observed. A segregation of some oxides which could form the $\left\{(\mathrm{Ca}, \mathrm{Mg}) \mathrm{SiO}_{4}\right\}$ phase that grows as light particles within the amorphous matrix has been also detected.

After this preliminary characterization of the slag generated just after the Mg-treatment, another group of four slag samples were progressively obtained from a Mg-treated batch. As it has been mentioned in the experimental section, this Mg-treated melt was initially sampled and then it was maintained in the ladle for $30 \mathrm{~min}$. Thus, three additional slag samples were extracted in this period in order to study the evolution of the chemical composition and the involved phases present. The amount of formed slag was high during the two first sampling practices and decreased for the rest of samples. Furthermore, the last slag sample showed a more fluid morphology than the other when picking it up from the melt. Table 7 shows the chemical evolution of the batch, while it was kept in the ladle in contact with the open air. The effect of the remaining time is more noticeable by the reduction of carbon, magnesium and cerium contents in the alloy due to the progressive oxidation of these elements. In case of aluminum and silicon content, reductions are also observed due to the same fact.

The continuous reduction detected in the content of these elements present in the liquid alloy leads to the formation of oxide compounds that become the main constituents of the slag finally obtained. Table 8 shows the evolution of the chemical composition of slag samples that were collected in this part of the study. It is worth noting that the SL-1 sample, i.e., the slag sample firstly obtained from the batch, shows the highest $\mathrm{SiO}_{2}$ content, while the highest $\mathrm{MgO}, \mathrm{CeO}_{2}$ and $\mathrm{La}_{2} \mathrm{O}_{3}$ contents are obtained in the last sample collected (SL-4). These results indicate that silicon gradually decreases its contribution to the slag composition, whereas the opposite behavior is found for magnesium, cerium and lanthanum. Finally, the $\mathrm{Al}_{2} \mathrm{O}_{3}$ and $\mathrm{CaO}$ contents evolution remains similar in all slag samples for the period of time studied in this work.

Apart from the amorphous matrix, the most important crystalline phases detected in all SL slag samples are spinel $\left(\mathrm{MgAl}_{2} \mathrm{O}_{4}\right)$, forsterite $\left\{(\mathrm{Mg}, \mathrm{Fe})_{2} \mathrm{SiO}_{4}\right\}$ and monticellite $\left\{(\mathrm{Ca}, \mathrm{Mg}) \mathrm{SiO}_{4}\right\}$. These three main constituents were also detected in the SLT samples (monticellite phase only was detected in the SLT samples by SEM inspection). Other minor crystalline phases detected are periclase $(\mathrm{MgO})$ and $\mathrm{SiO}_{2}$ as quartz and cristobalite. Figure 3 shows the indexed diffractogram obtained from the SL-4 sample, i.e., the last slag sample extracted from the batch when temperature was $1333{ }^{\circ} \mathrm{C}\left(2431^{\circ} \mathrm{F}\right)$ and the remaining time in the ladle was $30 \mathrm{~min}$. In this diffractogram, it is possible to check all the crystalline phases mentioned above. Additional peaks of moissanite (SiC) and graphite (both are non-dissolved additives used in the melting procedure) were also detected in sample SL-1, whereas only the latter was present in the SL-2 sample. Non-dissolved additives were also detected in the slag samples obtained after melting rich steel scrap charges in the melting furnaces (Ref. part I).

The results obtained from the SEM characterization of all SL samples are in good agreement with the phases 


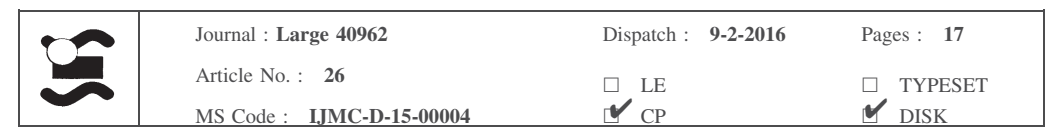

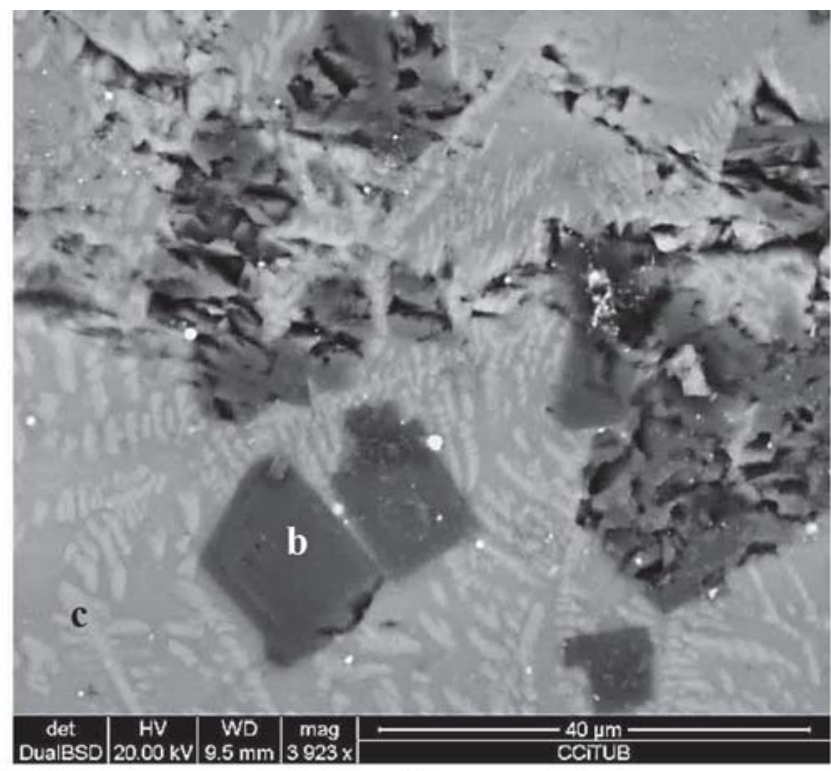

(a)

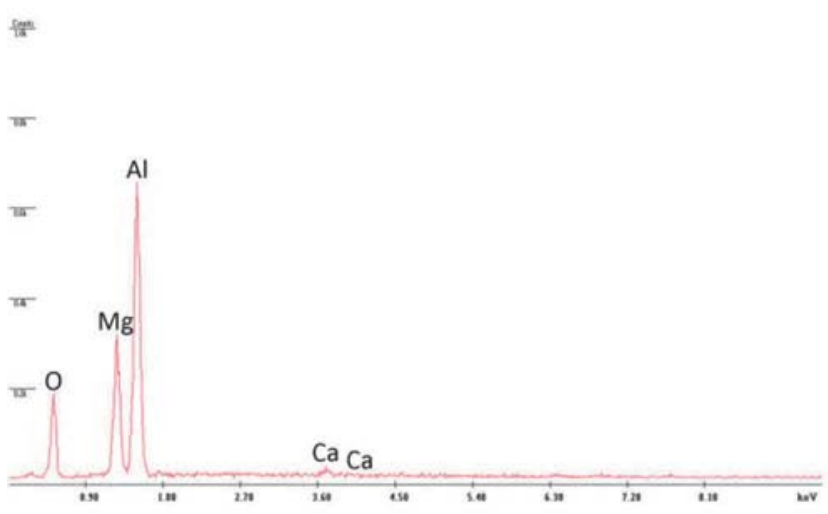

(b)

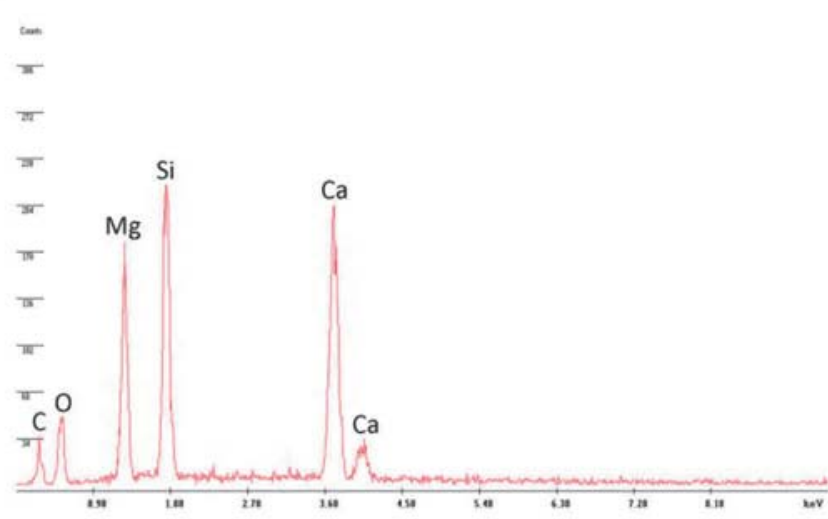

(c)

Figure 2. (a) SEM micrograph of SLT-1 sample. EDS microanalyses of (b) dark particles with a spinel-like $\left(\mathrm{MgAl}_{2} \mathrm{O}_{4}\right)$ composition and (c) of light particles with a composition that fits to the monticellite $\left\{(\mathrm{Ca}, \mathrm{Mg}) \mathrm{SiO}_{4}\right\}$ phase growing inside the amorphous matrix.

Table 7. Chemical Evolution of Melt During the Progressive Sample Extraction (wt\%)

\begin{tabular}{|c|c|c|c|c|c|c|c|c|c|}
\hline Sample & C & $\mathrm{Mn}$ & $\mathrm{Si}$ & $S$ & $\mathrm{Mg}$ & $\mathrm{Al}$ & $\mathrm{Ti}$ & $\mathrm{Ce}$ & $\mathrm{Zn}$ \\
\hline SL-1 & 3.72 & 0.23 & 2.52 & 0.008 & 0.041 & 0.0069 & 0.039 & 0.0111 & 0.150 \\
\hline SL-2 & 3.71 & 0.23 & 2.49 & 0.009 & 0.038 & 0.0066 & 0.039 & 0.0111 & 0.153 \\
\hline SL-3 & 3.68 & 0.23 & 2.47 & 0.009 & 0.039 & 0.0063 & 0.039 & 0.0104 & 0.156 \\
\hline SL-4 & 3.67 & 0.23 & 2.46 & 0.009 & 0.036 & 0.0060 & 0.039 & 0.0099 & 0.156 \\
\hline
\end{tabular}

407 identified by XRD. Figure 4 shows a SEM micrograph 408 recorded on the SL-2 sample, and the EDS microanalysis 409 spectra obtained from the different phases marked on the 410 micrograph. The three main phases detected by XRD in all 411 SL samples have been confirmed by SEM studies. Note 412 that EDS microanalysis of the amorphous phase (Fig413 ure 4c) shows peaks of the most relevant elements that 414 have also been detected by XRF (Table 8).

\section{Slag Compounds Generated in the Pouring Step}

Both the pouring basin and the recharge spout of the pressure pour furnace are in contact with open air, so the oxidation of magnesium and other elements that are present in the melt continuous and significant amounts of slag is also formed in there. On the other hand, composition of slag formed in the pressure pour device becomes 


\begin{tabular}{|l|lll|}
\hline Journal : Large 40962 & Dispatch : 9-2-2016 & Pages : 17 \\
& Article No. : 26 & $\square$ LE & $\square$ TYPESET \\
MS Code : IJMC-D-15-00004 & $\square_{\text {CP }}$ & $\checkmark$ DSK \\
\hline
\end{tabular}

Table 8. Evolution of the Chemical Composition of Slag Formed in the Same Batch (wt\%)

\begin{tabular}{llllllllr}
\hline Sample & $\mathrm{SiO}_{2}$ & $\mathrm{Al}_{2} \mathrm{O}_{3}$ & $\mathrm{CaO}$ & $\mathrm{MgO}$ & $\mathrm{Fe}_{2} \mathrm{O}_{3}$ & $\mathrm{SO}_{3}$ & $\mathrm{CeO}_{2}$ & $\mathrm{La}_{2} \mathrm{O}_{3}$ \\
\hline $\mathrm{SL}-1$ & 37.20 & 18.00 & 16.43 & 15.09 & 8.44 & 1.13 & 1.45 & $<1.00$ \\
$\mathrm{SL}-2$ & 33.29 & 20.91 & 17.58 & 22.13 & 1.47 & $<1.00$ & 1.98 & 1.14 \\
$\mathrm{SL}-3$ & 34.02 & 18.57 & 17.32 & 21.35 & 4.43 & $<1.00$ & 1.88 & 1.10 \\
$\mathrm{SL}-4$ & 25.92 & 16.07 & 16.03 & 28.74 & 7.62 & $<1.00$ & 2.59 & 1.52 \\
\hline
\end{tabular}

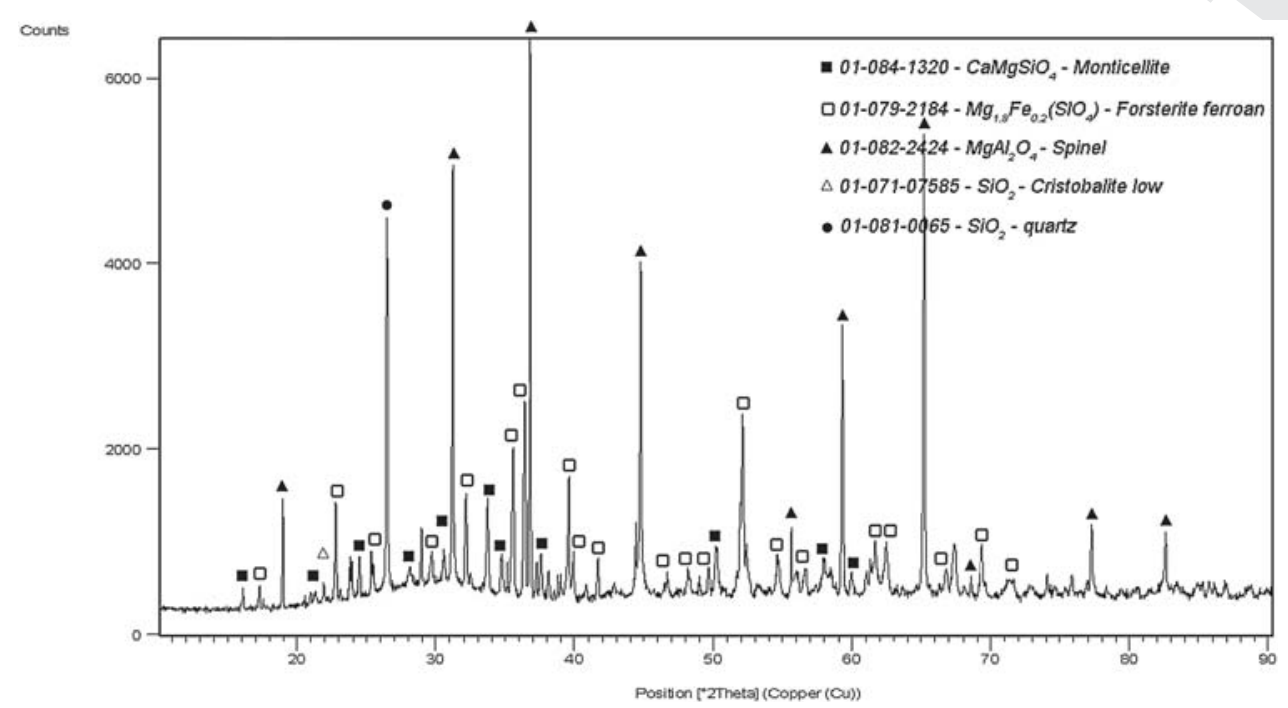

Figure 3. Indexed X-ray diffractogram recorded from the slag sample SL-4.

interesting as it is expected to be very similar to the one found on slag inclusions detected in the produced parts. Thus, three different SPF samples were collected in the pouring area so as to comparatively study their chemical and structural features. Table 9 includes the chemical composition of melts during sampling procedure. Notice that all three compositions are quite similar and they are also comparable to the chemical composition exhibited by the SL-3 and SL-4 samples (Table 7).

The chemical analysis of the three SPF samples is shown in Table 10. As expected all of them exhibit similar compositions $\mathrm{SiO}_{2}$ and $\mathrm{MgO}$ being the main oxides by far. It is also worthy to remark here that the $\mathrm{ZnO}$ contents are considerably high when comparing them to the levels of this oxide obtained in the samples collected from melts that remained in the ladle (Tables 6,8). This difference could be explained by the accumulation of zinc compounds in the internal area of the pressurized pouring device. In fact, foundry plants usually have to remove important amounts of both zinc-bearing deposits and sublimated zinc when cleaning the melt holder of the pressurized pouring systems. The main source of zinc is the use of galvanized steel scrap as raw material.

On the other hand, the $\mathrm{Al}_{2} \mathrm{O}_{3}$ and $\mathrm{CaO}$ contents in all three SPF samples are lower than those found in the SLT and SL samples as a consequence of the lower availability of the involved elements to their oxidation in the pouring basin (notice that these elements are mainly added to the melt by FeSiMg ferroalloy). The MgO content is higher instead in SPF samples than in the SLT and SL ones due to the continuous oxidation of this element in the melt.

The most important phases found in slag formed in the pouring basin are shown in the diffractogram of Figure 5. In this case, the SPF-1 sample is mainly composed by forsterite $\left\{(\mathrm{Mg}, \mathrm{Fe})_{2} \mathrm{SiO}_{4}\right\}$ and spinel $\left(\mathrm{MgAl}_{2} \mathrm{O}_{4}\right)$. Other minor phases also detected are lanthanum oxysulphide $\left(\mathrm{La}_{2} \mathrm{O}_{2} \mathrm{~S}\right)$, zinc oxide $(\mathrm{ZnO})$, cerium oxide $\left(\mathrm{Ce}_{2} \mathrm{O}_{3}\right)$, periclase $(\mathrm{MgO})$, lanthanum oxide $\left(\mathrm{La}_{2} \mathrm{O}_{3}\right)$, calcium-cerium oxide $\left(\mathrm{Ce}_{0.9} \mathrm{Ca}_{0.1} \mathrm{O}_{1.9}\right)$ and willemite $\left(\mathrm{Zn}_{2} \mathrm{SiO}_{4}\right)$.

When comparing the chemical composition of SLT, SL and SPF samples, it is remarkable that $\mathrm{ZnO}$ contents are higher in the last group than in the others (Tables 6, 8, 10). This result is expected as zinc is accumulated in the pressure pour furnace and it is finally included in the slag obtained from this device. On the other hand, SEM inspection of SPF samples shows the common spinel $\left(\mathrm{MgAlO}_{4}\right)$ as the darkest particles as well as an extra phase which is indicated with arrows in Figure 6. This additional phase has not been detected in the SEM characterization of SLT and SL samples (Figures 2, 4, respectively). The EDS spectrum recorded from this new phase confirms the presence of zinc in addition to aluminum, magnesium and oxygen peaks. However, any phase containing these four elements has not 


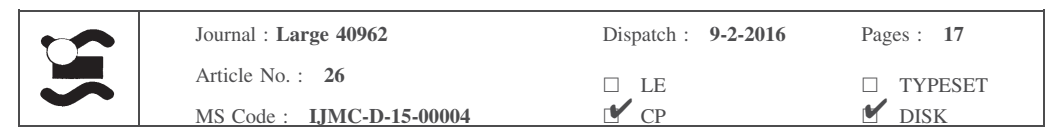
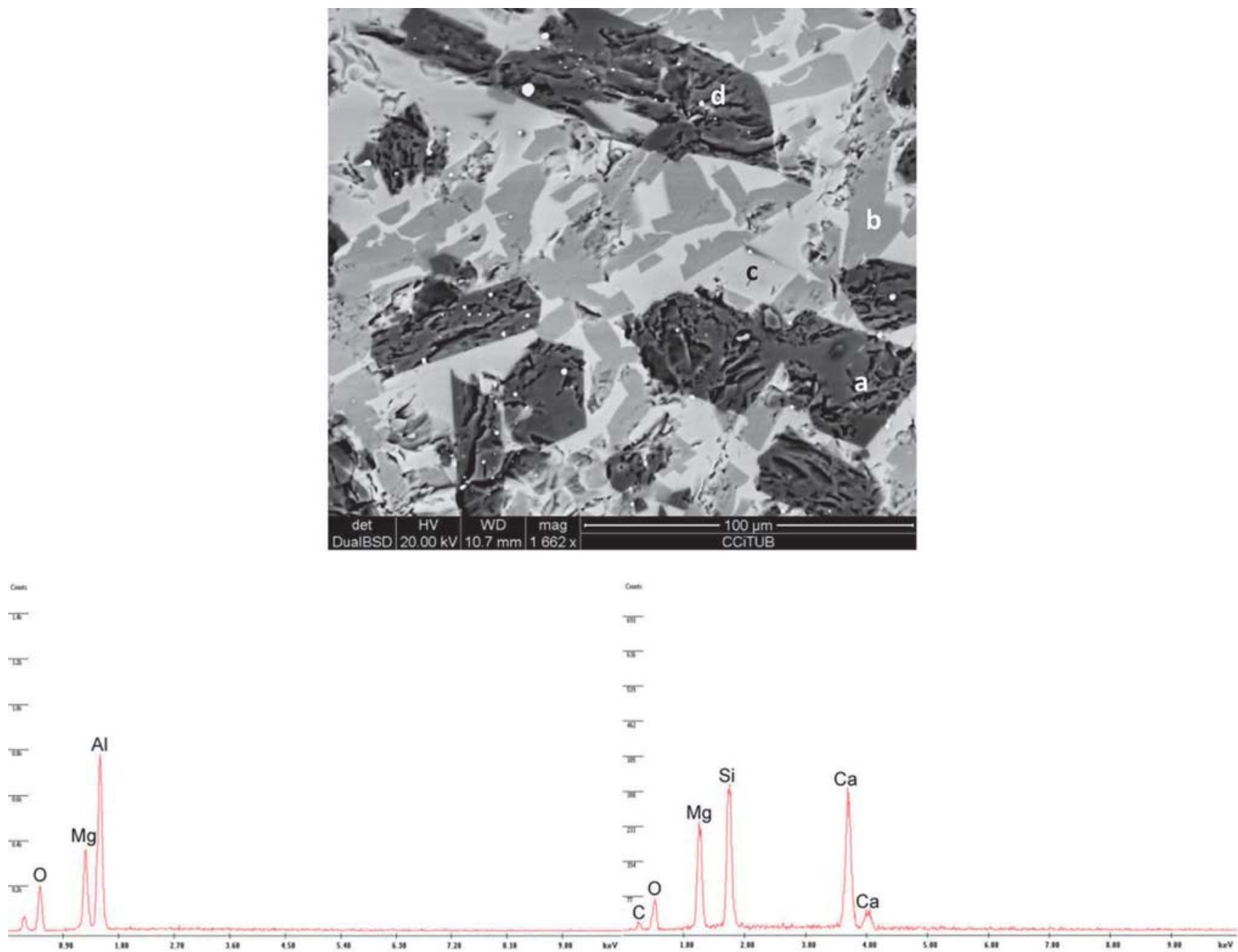

(a)

(b)

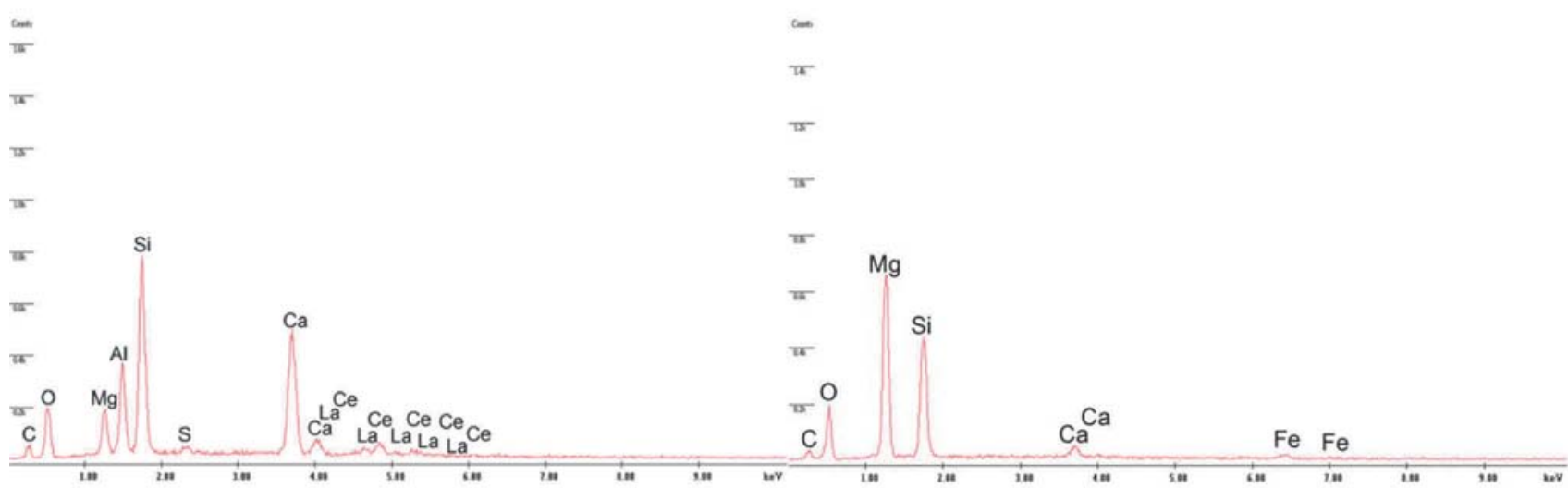

(c)

(d)

Figure 4. SEM micrograph of the SL-2 sample and EDS microanalysis of the different phases indicated as (a), (b), (c) and (d) in the image.

474 apparently been detected in the XRD analysis on SPF 47 AQ5 samples as has been described above. The explanation for 476 this fact is the formation of a mixed spinel $(\mathrm{Zn}, \mathrm{Mg}) \mathrm{Al}_{2} \mathrm{O}_{4}$ 477 where magnesium oxide of the $\mathrm{MgAl}_{2} \mathrm{O}_{4}$ spinel is partially substituted by zinc oxide both crystalline compounds with coincident XRD spectra. Thus, assignments done in Figure 5 should include these two spinel phases according to the results of the XRF and SEM studies. 


\begin{tabular}{|c|c|c|c|c|}
\hline & Journal : Large 40962 & Dispatch & 9-2-2016 & Pages: 17 \\
\hline & $\begin{array}{l}\text { Article No. : } 26 \\
\text { MS Code : } \quad \text { IJMC-D-15-00004 }\end{array}$ & $\begin{array}{l}\square \\
\boldsymbol{V}_{\mathrm{CP}}^{\mathrm{LE}}\end{array}$ & & $\begin{array}{l}\square \text { TYPESET } \\
\boldsymbol{V} \text { DISK }\end{array}$ \\
\hline
\end{tabular}

Table 9. Chemical Composition of the Melt Present in the Pouring Basin (wt\%)

\begin{tabular}{|c|c|c|c|c|c|c|c|c|c|}
\hline Sample & C & $\mathrm{Mn}$ & $\mathrm{Si}$ & $S$ & $\mathrm{Mg}$ & $\mathrm{Al}$ & $\mathrm{Ti}$ & $\mathrm{Zn}$ & $\mathrm{Ce}$ \\
\hline SPF-1 & 3.67 & 0.37 & 2.48 & 0.003 & 0.033 & 0.0049 & 0.024 & 0.123 & 0.0100 \\
\hline SPF-2 & 3.70 & 0.37 & 2.43 & 0.003 & 0.034 & 0.0048 & 0.023 & 0.127 & 0.0084 \\
\hline SPF-3 & 3.67 & 0.37 & 2.47 & 0.004 & 0.035 & 0.0050 & 0.024 & 0.124 & 0.0093 \\
\hline
\end{tabular}

Table 10. Chemical Composition of Floating Slag Samples Collected from Melts Hold in the Pouring Basin (wt\%)

\begin{tabular}{llllllllll}
\hline Sample & $\mathrm{SiO}_{2}$ & $\mathrm{MgO}$ & $\mathrm{ZnO}$ & $\mathrm{Al}_{2} \mathrm{O}_{3}$ & $\mathrm{Fe}_{2} \mathrm{O}_{3}$ & $\mathrm{CeO}_{2}$ & $\mathrm{MnO}$ & $\mathrm{La}_{2} \mathrm{O}_{3}$ & $\mathrm{CaO}$ \\
\hline SPF-1 & 34.43 & 32.29 & 8.72 & 7.68 & 5.84 & 4.95 & 2.33 & 1.62 & 1.42 \\
SPF-2 & 33.55 & 29.03 & 8.47 & 10.09 & 5.14 & 4.24 & 1.63 & 1.32 & 2.75 \\
SPF-3 & 37.85 & 31.11 & 6.31 & 7.03 & 4.95 & 4.35 & 1.77 & 1.30 & 4.17 \\
\hline
\end{tabular}

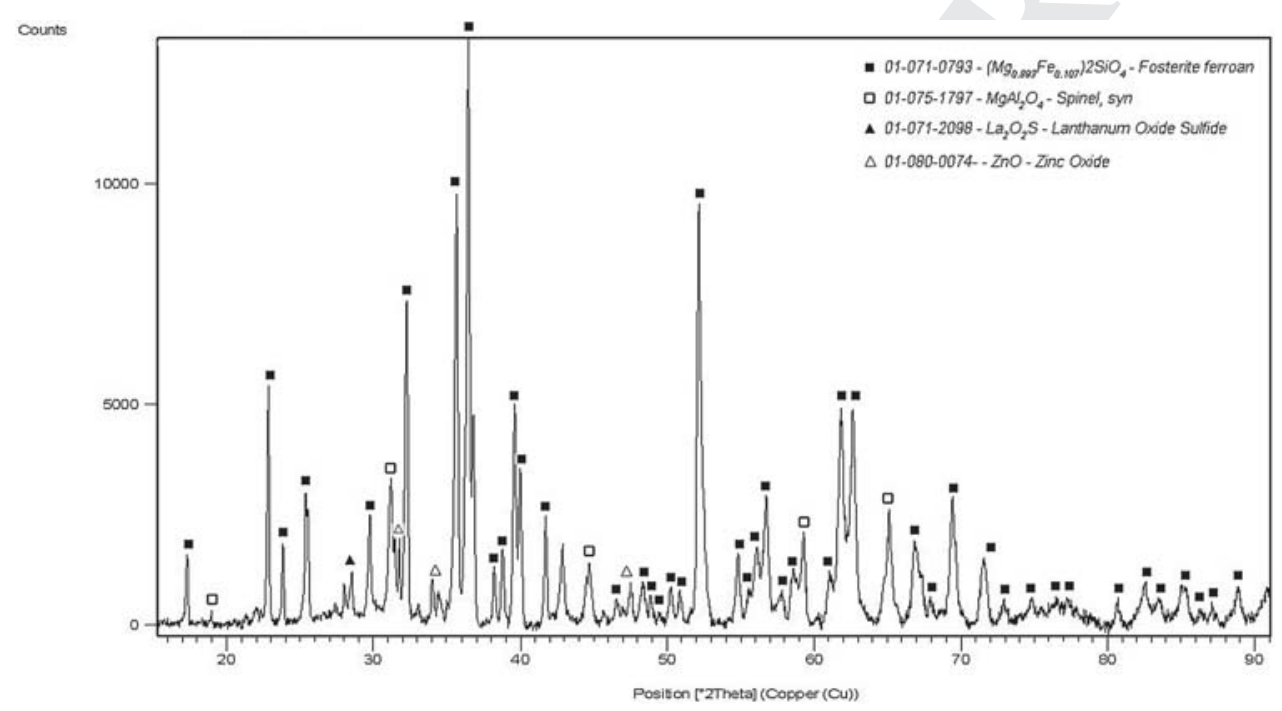

Figure 5. Diffractogram obtained on the SPF-1 sample.

482 Figure 7 shows another SEM micrograph this time 48 AQ6 obtained from the SPF-1 sample. Dark gray particles with a 484 485

EDS spectrum (Figure 7a) that matches with the forsterite crystalline phase growing in the amorphous part of the slag (pale gray areas marked as "c" on the micrograph). The white phase which is also observed shows peaks of silicon, oxygen, calcium, cerium and lanthanum possibly combined to form a silicate (Figure 7b). Notice the important zinc contamination detected on the amorphous part of this sample (Figure 7c).

\section{Slag Compounds Adhered to the Refractory Lining of the Pouring Furnace}

This section includes the characterization of four different slag samples stuck to different zones of the refractory lining present in the pouring device (see "Experimental Part" section). It has been assumed here that melt composition is analogous to that shown in Table 9. The chemical analyses obtained from these slag samples are included in Table 11 in which the chemical results are given in the form of oxides of the elements as well. However, some of these elements can be found as sulfides in the SIC and SIW samples before their calcination step. Because of this, the chemical results from these two samples show a significant concentration of $\mathrm{SO}_{3}$.

A comparison of data included in Table 11 shows strong differences on samples which are related to the selected sampling zone. Regarding this fact both SRS and SPB slag samples which were separated from the lining in the recharge spout and in the pouring basin, respectively, show a different composition than the two others that were obtained from the internal pressurized cavity of the pouring device. However, all the slag samples analyzed show a basic character ${ }^{2}$ as the refractory lining of the pouring furnace is mainly composed by alumina. 


\begin{tabular}{|l|ll|}
\hline Journal : Large 40962 & Dispatch : 9-2-2016 & Pages : 17 \\
Article No. : 26 & $\square$ LE & $\square$ TYPESET \\
MS Code : IJMC-D-15-00004 & $\cup_{\text {CP }}$ & $\checkmark$ DSK \\
\hline
\end{tabular}

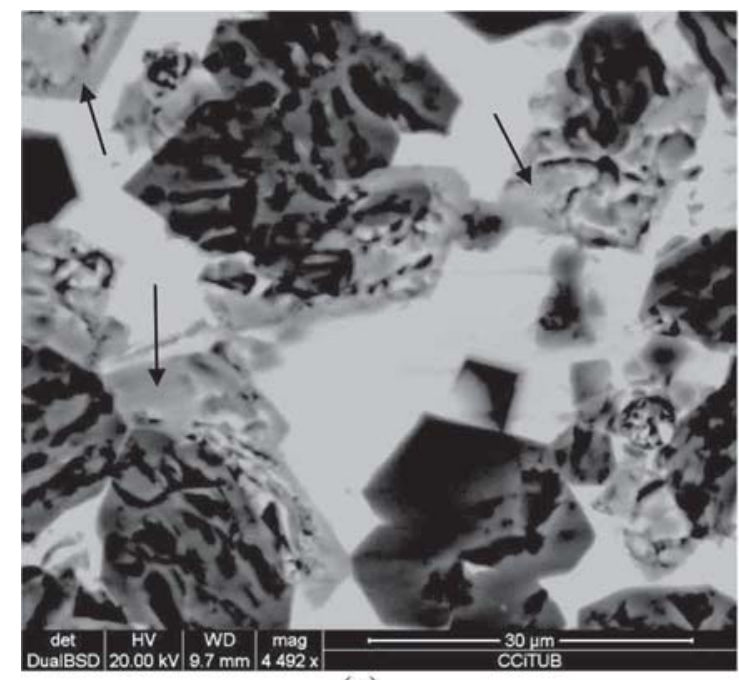

(a)

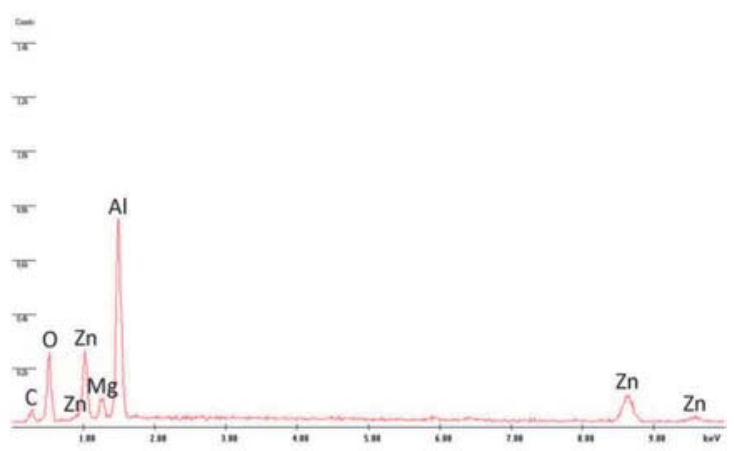

(b)

Figure 6. (a) SEM micrograph of SPF-3 sample and (b) EDS microanalyses of the particles indicated on it by arrows.
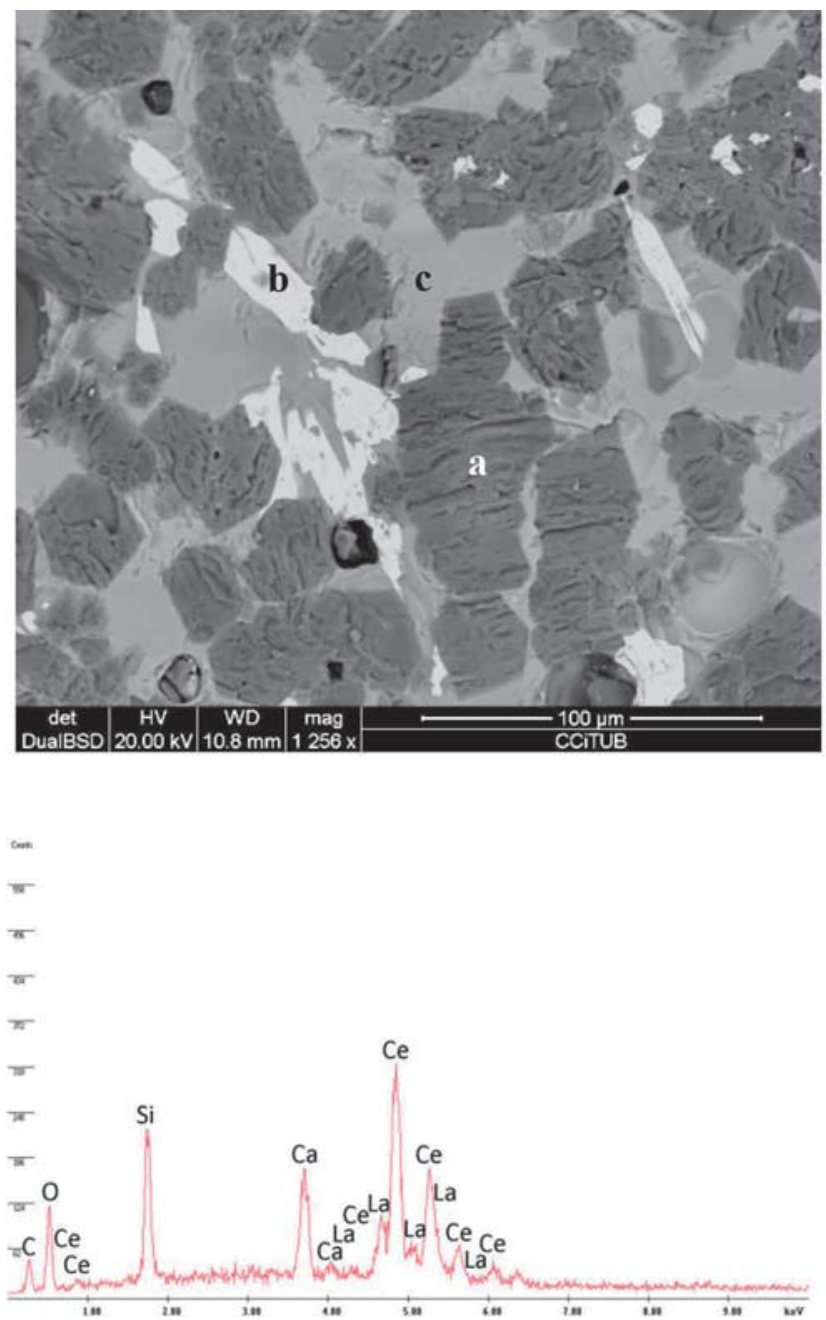

(b)

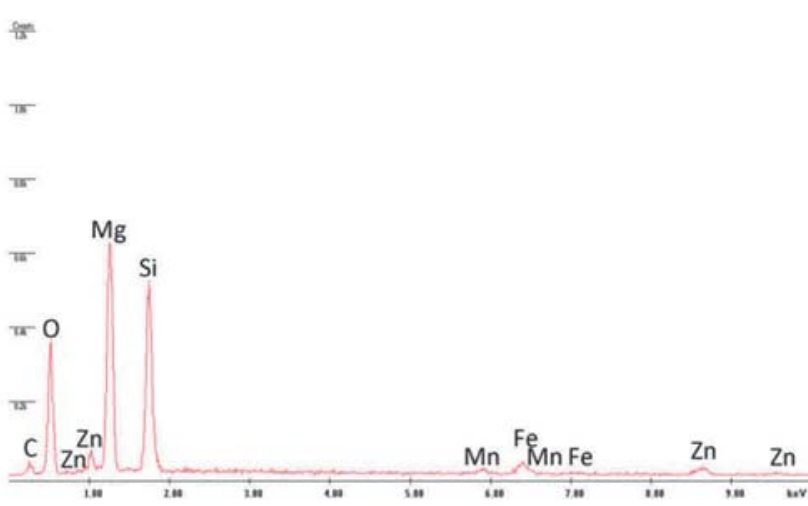

(a)

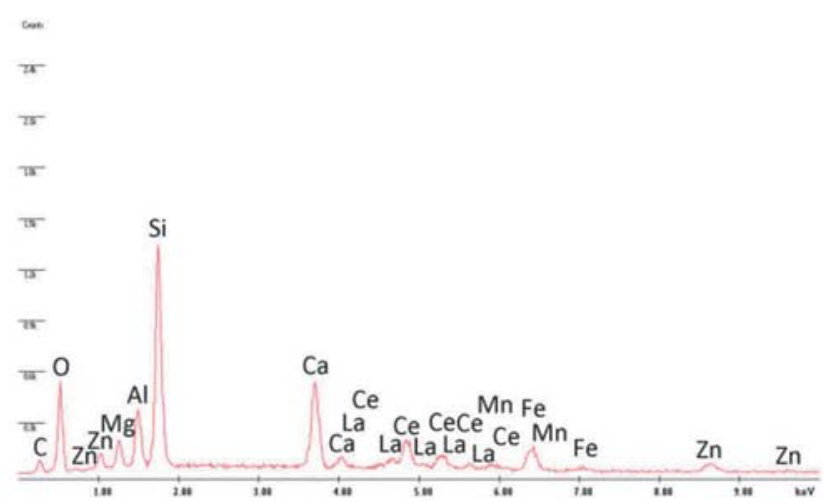

(c)

Figure 7. SEM micrograph of the SPF-1 sample and EDS microanalyses of the phases indicated on it. 


\begin{tabular}{|l|lll|}
\hline Journal : Large 40962 & Dispatch : 9-2-2016 & Pages : 17 \\
Article No. : 26 & $\square$ LE & $\square$ TYPESET \\
MS Code : IJMC-D-15-00004 & $\cup_{\text {CP }}$ & $\square$ DISK \\
\hline
\end{tabular}

Table 11. Chemical Composition of the Slag Samples Stuck to the Refractory Lining of the Pouring Device (wt\%)

\begin{tabular}{llrrrrrrr}
\hline Sample & $\mathrm{MgO}$ & $\mathrm{La}_{2} \mathrm{O}_{3}$ & $\mathrm{CeO}_{2}$ & $\mathrm{Fe}_{2} \mathrm{O}_{3}$ & $\mathrm{SO}_{3}$ & $\mathrm{CaO}$ & $\mathrm{SiO}_{2}$ & $\mathrm{Al}_{2} \mathrm{O}_{3}$ \\
\hline SIC & 30.22 & 27.26 & 15.63 & 10.37 & 10.28 & 5.54 & $<1.00$ & $<1.00$ \\
SIW & 53.43 & 7.47 & 5.98 & 7.77 & 7.80 & 6.35 & 1.18 & 9.82 \\
SRS & 31.03 & 1.85 & 2.77 & 16.28 & $<1.00$ & 11.31 & 16.11 & 18.32 \\
SPB & 34.12 & 4.10 & 4.51 & 22.52 & $<1.00$ & 1.47 & 21.34 & 9.48 \\
\hline
\end{tabular}

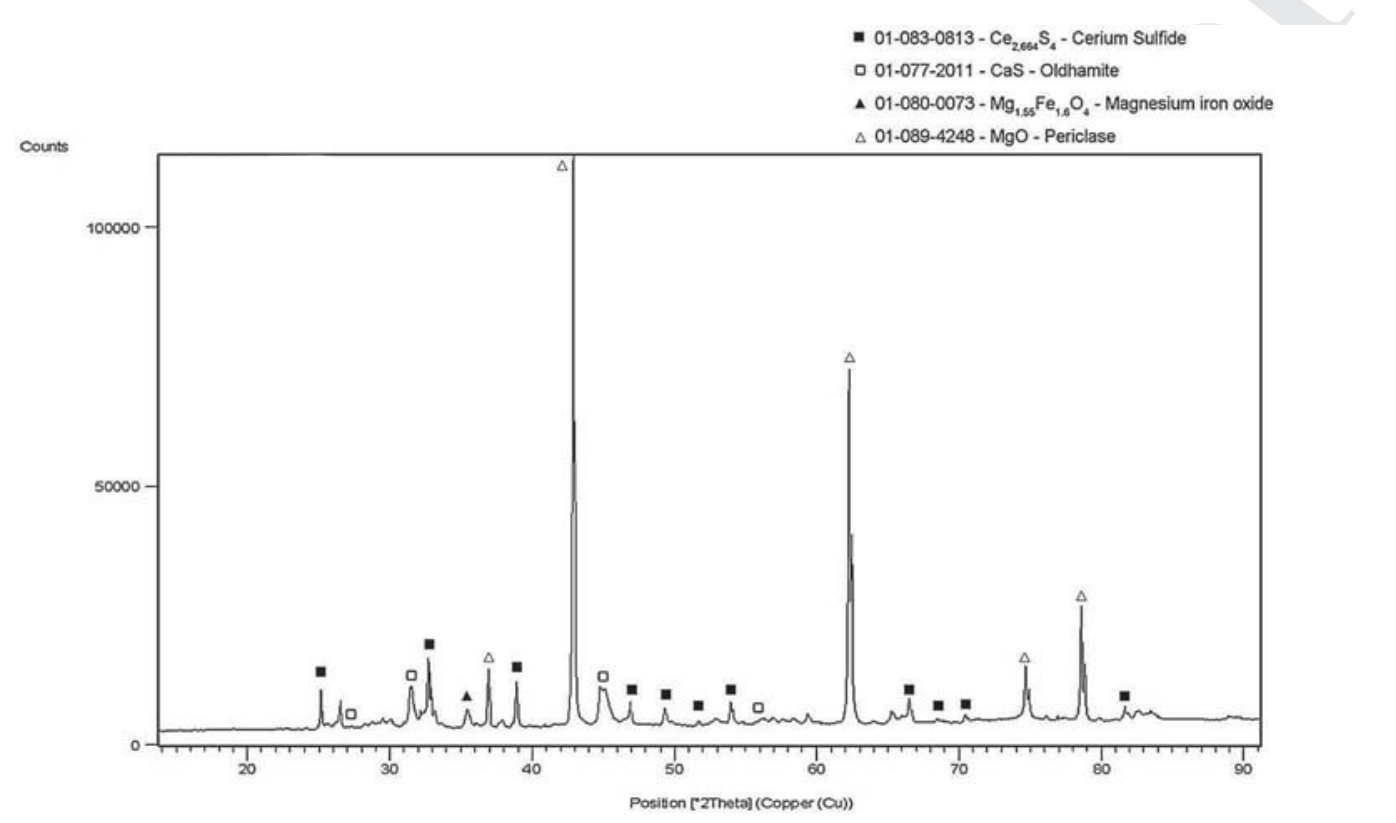

Figure 8. Diffractogram obtained from the slag sample SIW.

Notice that the "internal" slag samples (SIC and SIW) contain higher amounts of rare earth oxides and of $\mathrm{SO}_{3}$ than the SRS and SPB ones. It is known in the foundry practice that sulfides can be accumulated in the pressurized cavity. Regarding this fact accumulation effect could be a suitable explanation for the comparatively high $\mathrm{SO}_{3}$ levels detected on SIC and SIW samples. It is also observed that the SIW sample contains the highest $\mathrm{MgO}$ content as air oxidation of dissolved magnesium in this zone is expected to be the lowest. Thus, the amount of $\mathrm{Mg}$ and of rare earth elements dissolved in the melt of the internal cavity and available to form slag compounds adhered to the lining seems to be higher than in the external areas of the pouring device where these elements can be rapidly oxidized to form part of the floating slag (XRD characterization for SPF samples).

On the other hand, Table 11 shows that SRS and SPB slag samples contain the highest amounts of $\mathrm{SiO}_{2}$ and of $\mathrm{Fe}_{2} \mathrm{O}_{3}$ and their compositions become comparable to those found on slag samples collected from melts that were in the ladle and in the pouring basin (Table 10) where open air exposition is expected to be high. It is worth nothing also that melts are frequently exposed to air oxidation in recharge spouts and in pouring basins as slag formed in these two locations is cleaned very often by plant workers.

The two most important crystalline phases found on SIC and SIW slag samples were periclase $(\mathrm{MgO})$ and cerium sulfide $\left(\mathrm{Ce}_{2.664} \mathrm{~S}_{4}\right.$; Figure 8). Additionally calcium sulfide (CaS), hematite $\left(\mathrm{Fe}_{2} \mathrm{O}_{3}\right)$ and the mixed oxides $\mathrm{Mg}_{1.55} \mathrm{Fe}_{1.6} \mathrm{O}_{4}$ and $\mathrm{Ca}_{0.1} \mathrm{La}_{0.9} \mathrm{FeO}_{3}$ were also identified as minor crystalline phases on these two samples. The detection of these phases is in good agreement with the chemical composition obtained from these two samples (Table 11). In case of SRS and SPB samples, the main crystalline phases were however spinel $\left(\mathrm{MgAl}_{2} \mathrm{O}_{4}\right)$, monticellite $\left[(\mathrm{Ca}, \mathrm{Mg}) \mathrm{SiO}_{4}\right]$, forsterite $\left[(\mathrm{Mg}, \mathrm{Fe})_{2} \mathrm{SiO}_{4}\right]$ and a complex lanthanum silicate named as britholite, while their minor phases were $\mathrm{Mg}_{1.55} \mathrm{Fe}_{1.6} \mathrm{O}_{4}$, periclase $(\mathrm{MgO})$ and wustite $(\mathrm{FeO})$. The high silicon, iron and aluminum contents exhibited by these external slag samples change the chemical characteristics of the crystalline phases found on them. Notice that several phases found on SRS and SPB samples were also detected on samples collected from the melt surface in the pouring basin of the pressure pour furnace though no $\mathrm{Zn}$ compounds were present in the former cases. Again it is expected that oxidation capacity 


\begin{tabular}{|l|ll|}
\hline Journal : Large 40962 & Dispatch : 9-2-2016 & Pages : 17 \\
Article No. : 26 & $\square$ LE & $\square$ TYPESET \\
MS Code : IJMC-D-15-00004 & $\cup_{\text {CP }}$ & $\checkmark$ DSK \\
\hline
\end{tabular}

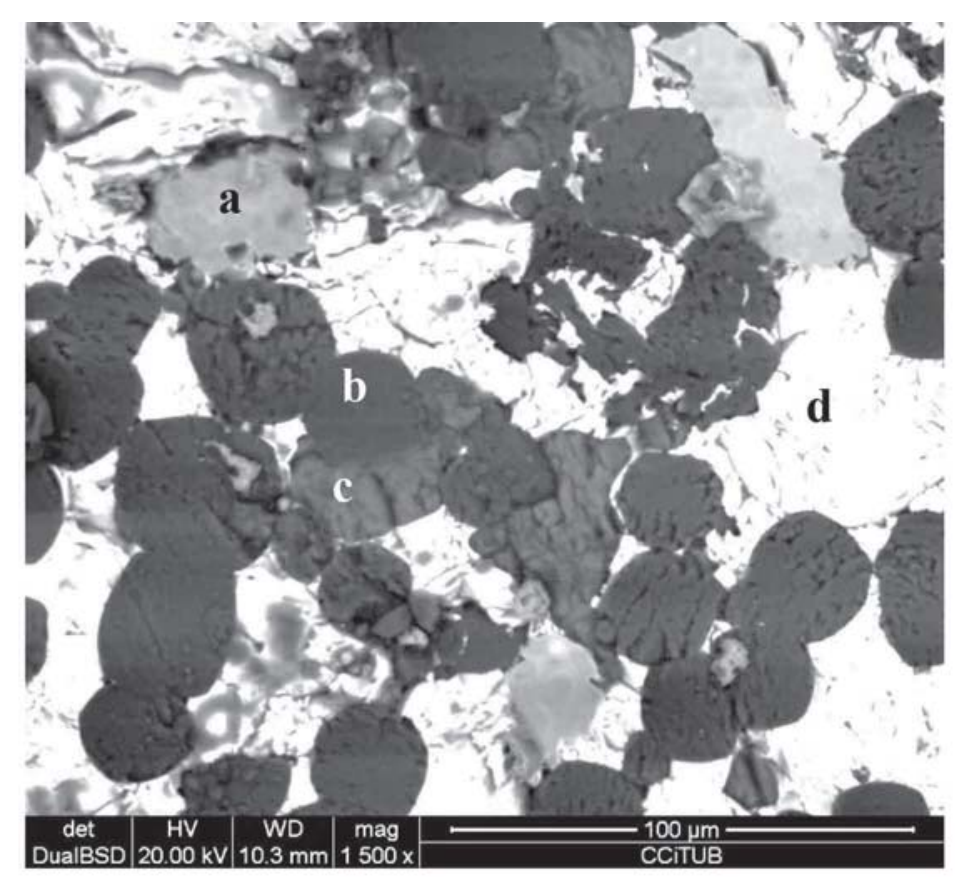

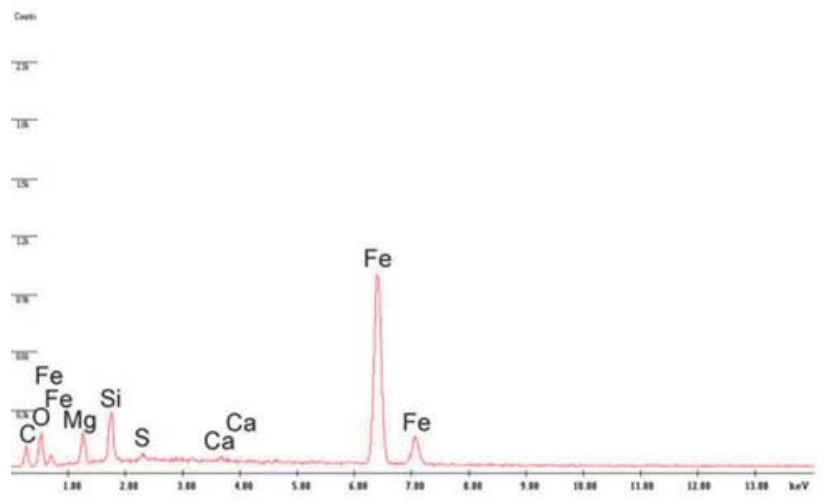

(a)

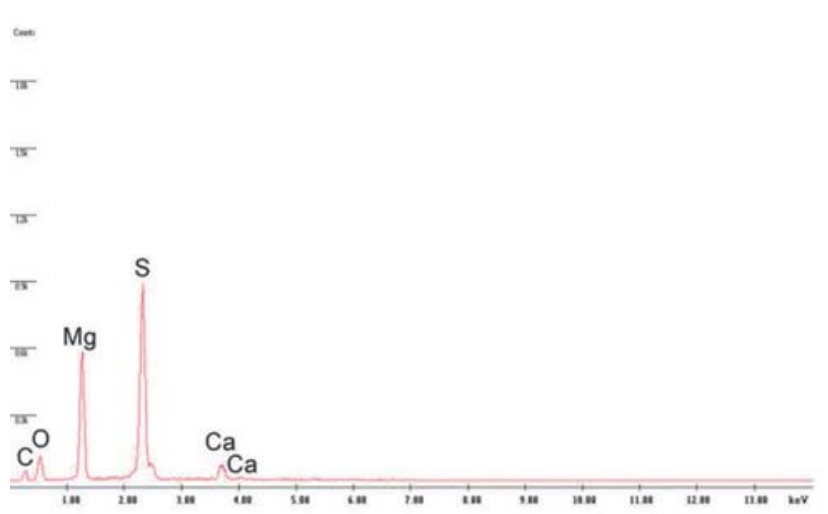

(c)

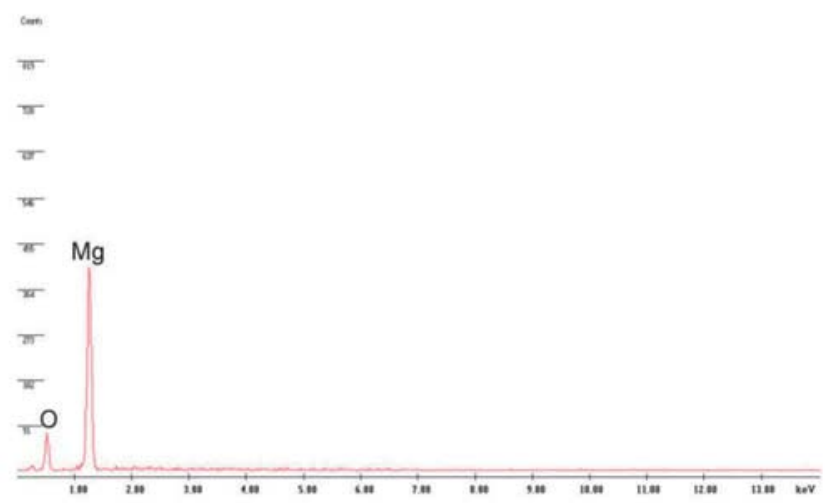

(b)

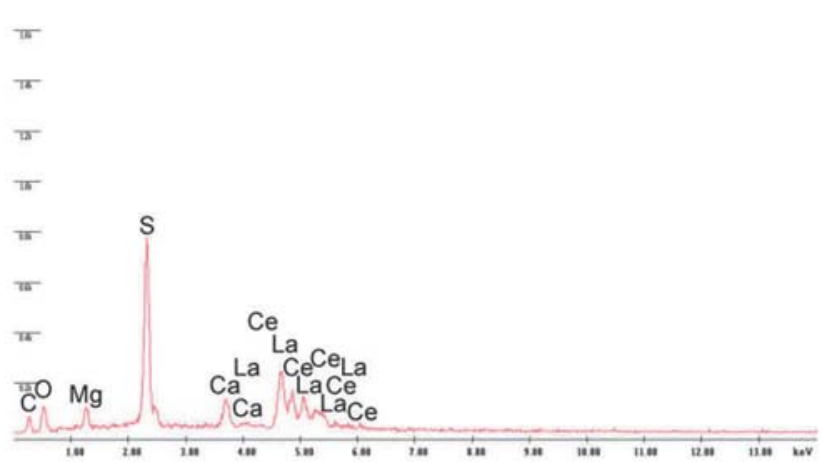

(d)

Figure 9. SEM micrograph of SIC sample and EDS microanalyses of the different particles indicated in it.

562 of slag samples according to their location in the pouring 563 device has a relevant effect on their composition.

564 Inspection of SIC and SIW samples by SEM led to identify 565 four different particles as it is shown in the micrograph included in Figure 9 which was recorded on the SIC sample. The results obtained from the EDS microanalyses performed on these phases reveal peaks that are coincident with the chemical compounds detected by XRD technique. Spectrum b of Figure 9 was obtained from the most 


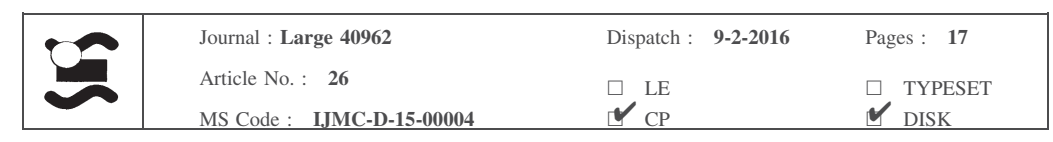

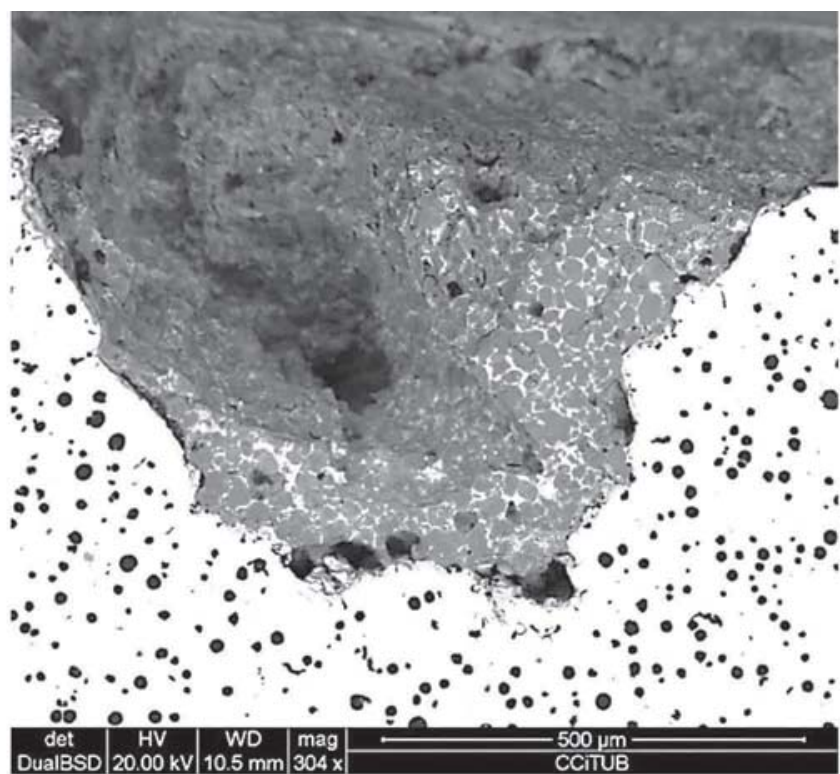

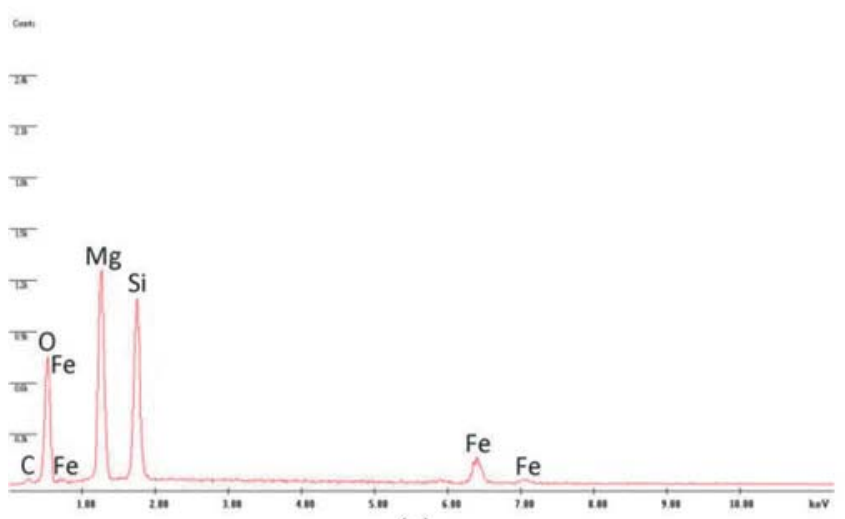

(a)

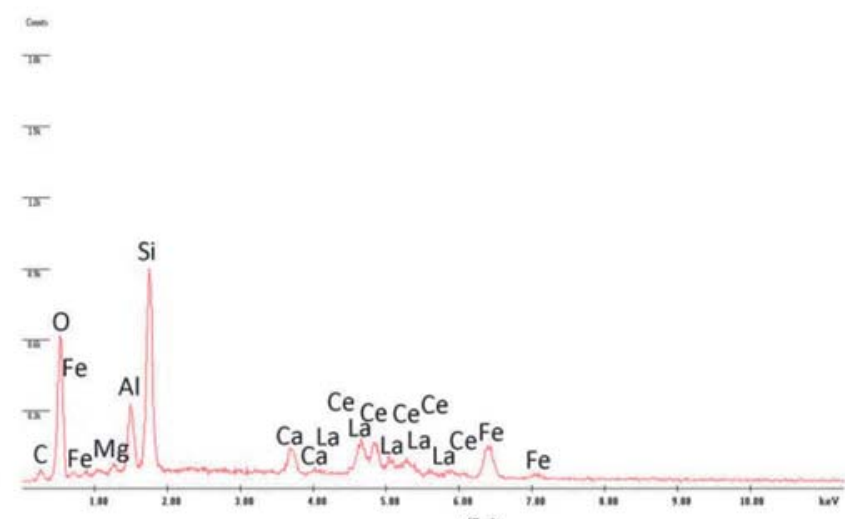

(b)

Figure 10. SEM micrograph of a slag inclusion present in a SG cast part. Below EDS microanalyses (a) of the gray phase and (b) of the white one.

abundant particles and matches well with the periclase $(\mathrm{MgO})$ phase, while spectra a, c and d included in the same figure show peaks of the different elements that were identified as constituents of other crystalline phases detected on these two samples. In case of SRS and SPB samples, a high number of different particles were also found in their SEM characterization. It is necessary to stress here that EDS peaks obtained on these slag samples are also in a good agreement with the results of the XRD study.

\section{Slag Inclusions Found in SG Cast Iron Parts}

Finally, the slag inclusions detected in SG castings will be studied. Samples characterization in this chapter has been exclusively done by SEM-EDS technique as it is the most usual method for determining the origin of inclusions on cast iron parts. Slag inclusions found in SG parts can be usually found as bulk particles or as stringers (dross inclusions). In a first step, it could be expected that slag inclusions found in the cast parts should contain phases and should show chemical compositions similar to those detected on slag compounds collected from the melt surface in the pouring basin. Figure 10 shows the SEM micrographs obtained on a representative slag inclusion that was found when inspecting a group of produced parts. In this case, the morphology of the defect was found to be similar to a bulk particle included in the metallic matrix and close to the external surface of the cast part. Two different constituents are well distinguished by different contrast: the gray one which becomes more abundant than the white one. EDS microanalyses performed on these two phases are also included in Figure 9.

The gray constituent mostly contains magnesium, silicon and oxygen, and it shows a similar EDS spectrum (Figure 10a) to one registered on SPF samples (Figure 6b) where forsterite $\left[(\mathrm{Mg}, \mathrm{Fe})_{2} \mathrm{SiO}_{4}\right]$ was found as the main crystalline phase. On the other hand, the lighter constituent shows peaks of cerium and lanthanum in a spectrum 


\begin{tabular}{|c|c|c|c|c|}
\hline & Journal : Large 40962 & Dispatch & 9-2-2016 & Pages: 17 \\
\hline & $\begin{array}{l}\text { Article No. : } 26 \\
\text { MS Code : } \quad \text { IJMC-D-15-00004 }\end{array}$ & $\begin{array}{l}\square \\
\boldsymbol{V}_{\mathrm{CP}}^{\mathrm{LE}}\end{array}$ & & $\begin{array}{l}\square \text { TYPESET } \\
\boldsymbol{V} \text { DISK }\end{array}$ \\
\hline
\end{tabular}

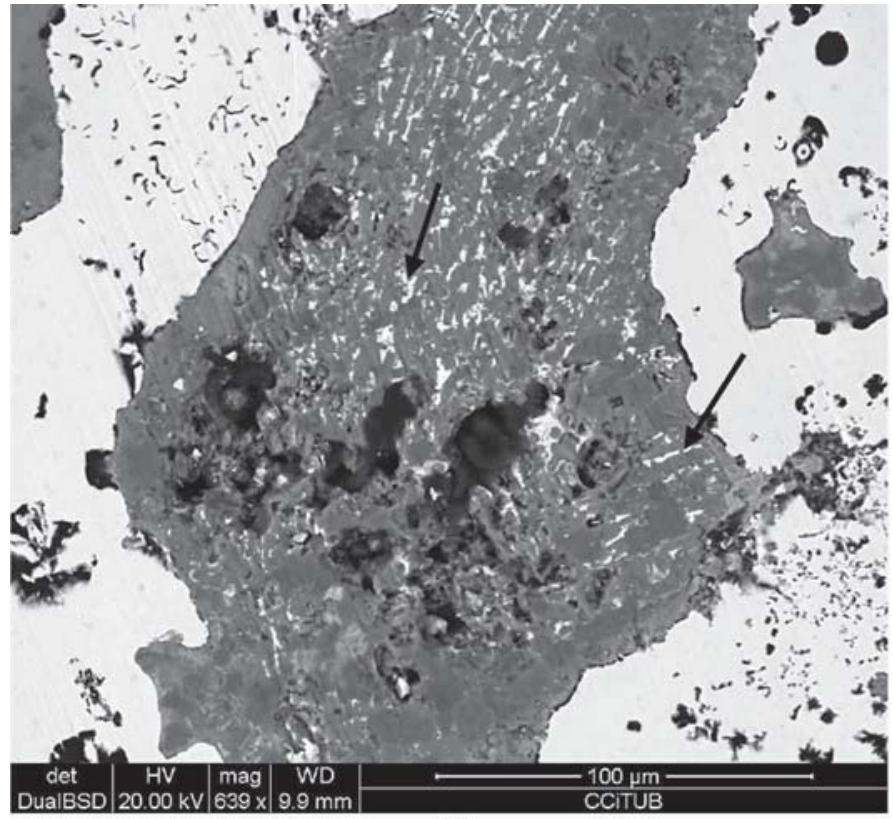

(a)

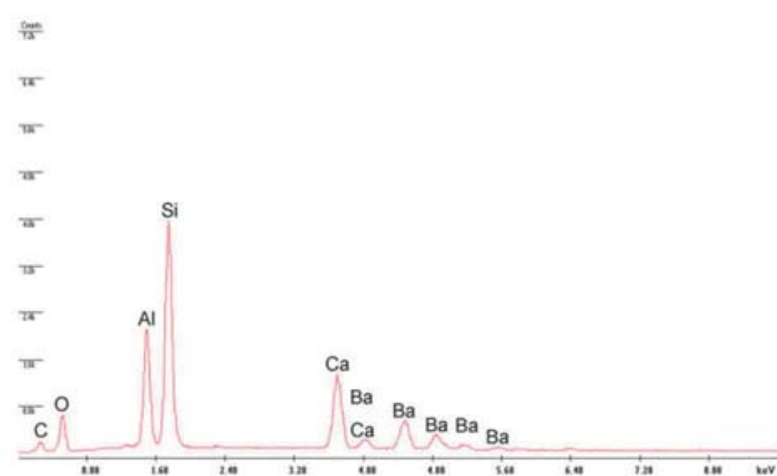

(b)

Figure 11. (a) SEM micrograph of amorphous slag sample and (b) EDS microanalysis of the white elongated particles marked in the micrograph.

608 (Figure 10b) which is also similar to the one obtained from 609 the SPF samples (Figure 6d) where several binary and complex rare earth oxides were detected by XRD analysis. Therefore, it can be assumed here that the origin of the analyzed slag inclusion is related to slag compounds formed in the pouring basin taking in account their similar composition. In other words, this slag inclusion found in the cast part was likely formed before pouring the mold.

Sand grains and/or rests of inoculant can also be found embedded in slag inclusions detected on manufactured cast parts. Figure 11 shows a SEM micrograph of a slag inclusion whose morphology and composition are similar to the one described in Figure 10 but with an important number of white small elongated particles. The EDS microanalysis made on these small stick-shaped particles shows that they contain barium, aluminum and calcium (Figure 11b) all of them present in the inoculant product used when manufacturing the cast parts. The presence of inoculant rests can also indicate that this type of slag inclusions was formed before pouring the molds and the rests of inoculant were incorporated during the mold filling process. In case of these slag inclusions with sand grains (Figure 12), it is expected that these grains were included due to erosion phenomena during the filling process.

As it has been indicated at the beginning of this chapter slag inclusions can show a stringer morphology commonly called as "dross inclusions." An example of this type is shown in Figure 13a where the inclusion is $3 \mathrm{~mm}$ (0.12 in.) in total length. Figure $13 \mathrm{~b}$ shows a more detailed view of one slag particle which is surrounded by an important number or dark thin lamellae. The EDS microanalysis of the slag particle revealed a typical spectrum with magnesium, silicon and oxygen peaks (Figure 13c). Both slag morphology and the lack of other elements found in SPF samples like iron, calcium and/or rare earth elements suggest that dross inclusions are a consequence of local oxidation of magnesium and silicon due to turbulences during filling the molds. In other cases, dross inclusions can be appeared together with bulk-shaped slag inclusions (indicated by arrows in Figure 14). As it is shown in the spectrum of this figure, the last defect also contains calcium in addition to the elements typically found in this kind of slag compounds. The EDS microanalysis made on the small lamellae indicates that they are composed by iron and oxygen (Figure 13d).

\section{Conclusions}

A group of 16 slag samples obtained from Mg-treated melts during nodulization and pouring processes and 5 slag inclusions from manufactured SG cast parts have been comparatively studied in the present work. The most relevant conclusions are the following:

1. The highest $\mathrm{SiO}_{2}$ (found as quartz or cristobalite crystalline phases) amounts were only detected on the slag samples STL extracted from the treatment ladle. The high oxidizing media present in the ladle promote the formation of this compound as the main constituent of slag. Despite this fact other phases like spinel 


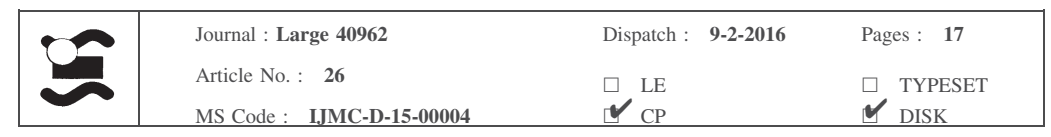

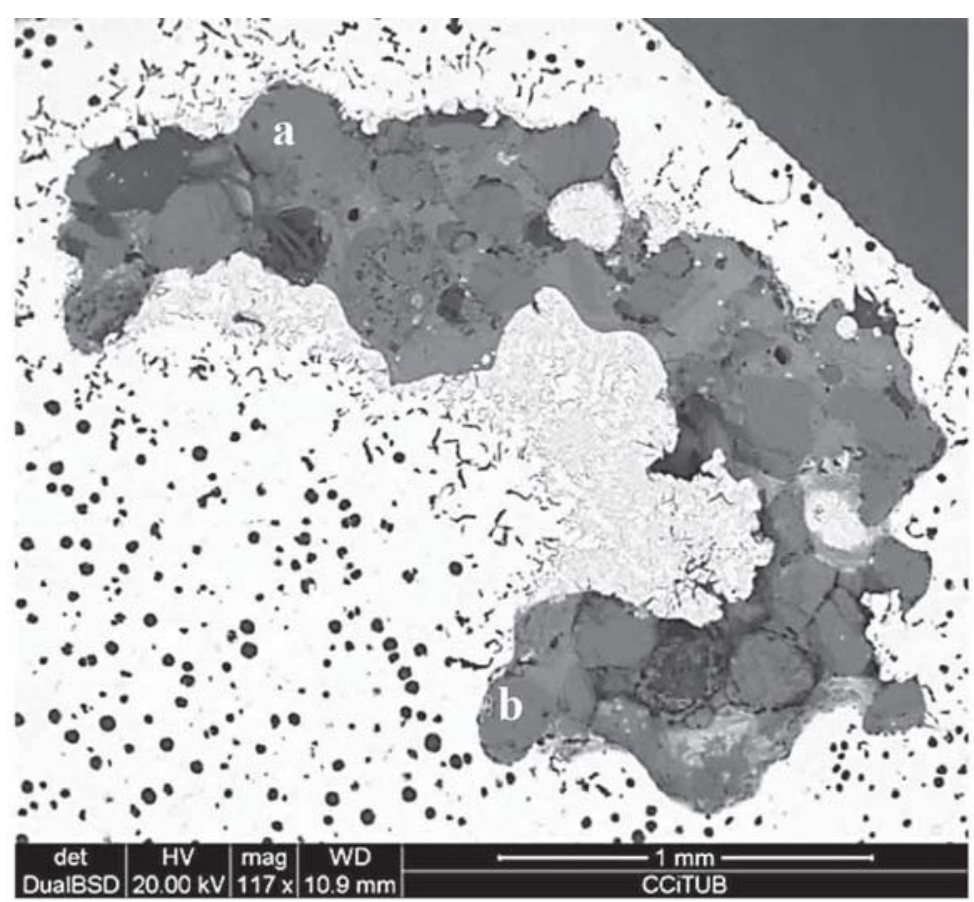

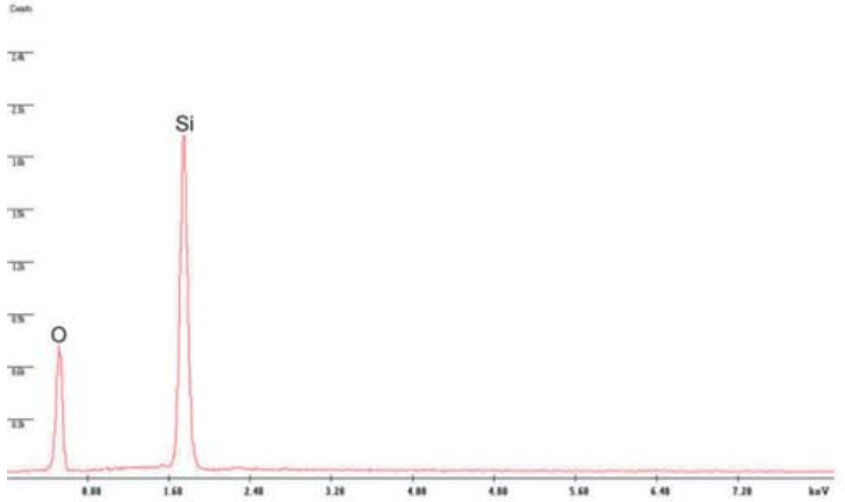

(a)

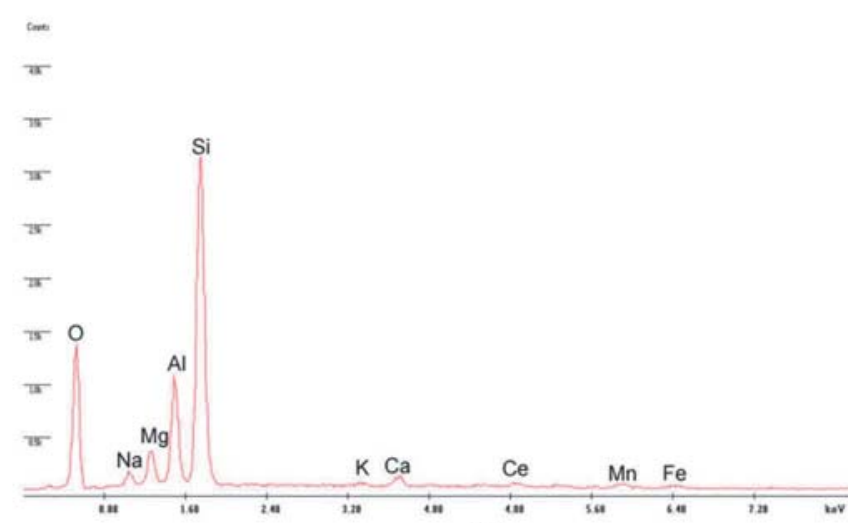

(b)

Figure 12. SEM micrograph of a bulk slag inclusion with sand and bentonite grains embedded with the slag (a) microanalysis EDS of the sand grains and (b) microanalysis EDS of the bentonite particles.

$\left(\mathrm{MgAl}_{2} \mathrm{O}_{4}\right)$ and forsterite $\left[(\mathrm{Mg}, \mathrm{Fe})_{2} \mathrm{SiO}_{4}\right]$ are also relevant constituents of these slag samples.

2. When a Mg-treated batch is maintained in the nodulization ladle quartz phase formation progressively decreases in the slag and silicon evolves to form different silicates. On the contrary, the amount of spinel, other Mg-bearing silicates and periclase $(\mathrm{MgO})$ increases due to progressive oxidation of magnesium and of rare earth elements. No significant differences were found regarding the type of compounds present in the slag samples SL extracted of the treatment ladle.

3. Slag which is formed and then remains floating in the melt surface of the pouring basin is mainly composed by silicon and magnesium. Thus, the main crystalline phase detected on this slag is the forsterite, followed by spinel, periclase and a rare earth complex oxide. On the other hand, the crystalline phase gahnite $\left(\mathrm{ZnAl}_{2} \mathrm{O}_{4}\right)$ and other zinc-bearing phases (silicates, aluminates and $\mathrm{ZnO}$ ) are also present in an important amount due to zinc accumulations that are commonly found in the pressurized cavity of the pressure pour furnace.

4. Regarding slag samples stuck to the refractory lining of the pressure pour furnace, significant differences have been found depending on the area of sampling. Samples collected from the internal cavity are mainly composed by periclase, cerium sulfide $\left(\mathrm{Ce}_{2.664} \mathrm{~S}_{4}\right)$ and minor amounts of other phases as magnesium sulfide, lanthanumbearing compounds and calcium sulfide $(\mathrm{CaS})$. Conversely slag samples obtained from the 


\begin{tabular}{|l|lll|}
\hline Journal : Large 40962 & Dispatch : 9-2-2016 & Pages : 17 \\
Article No. : 26 & $\square$ LE & $\square$ TYPESET \\
MS Code : IJMC-D-15-00004 & $\cup_{\text {CP }}$ & $\checkmark$ DISK \\
\hline
\end{tabular}

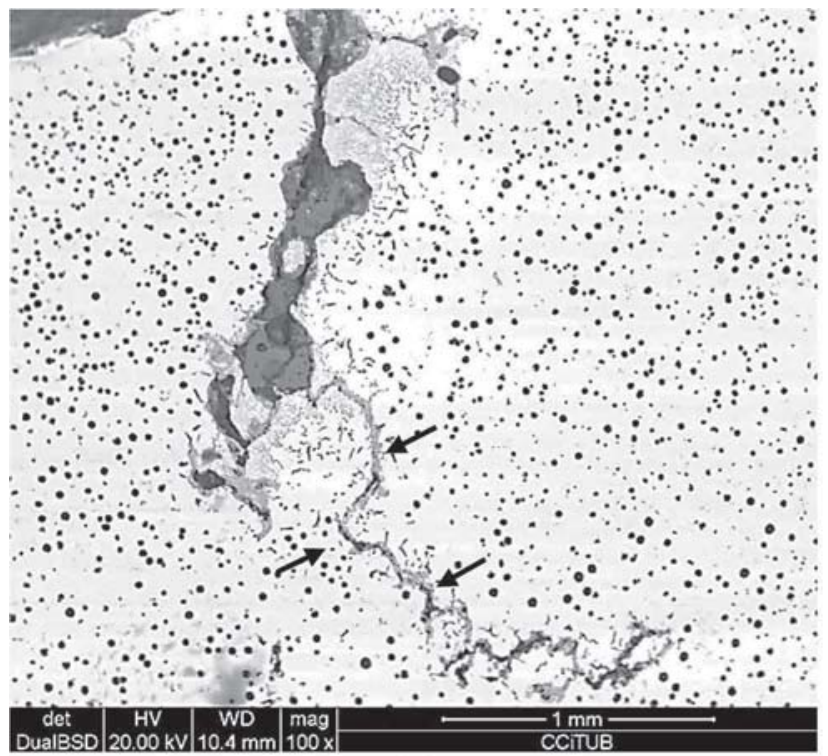

(a)

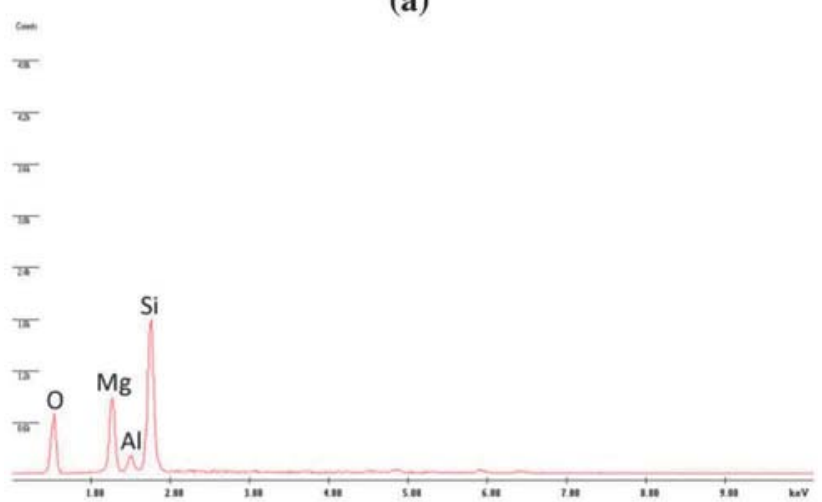

(c)

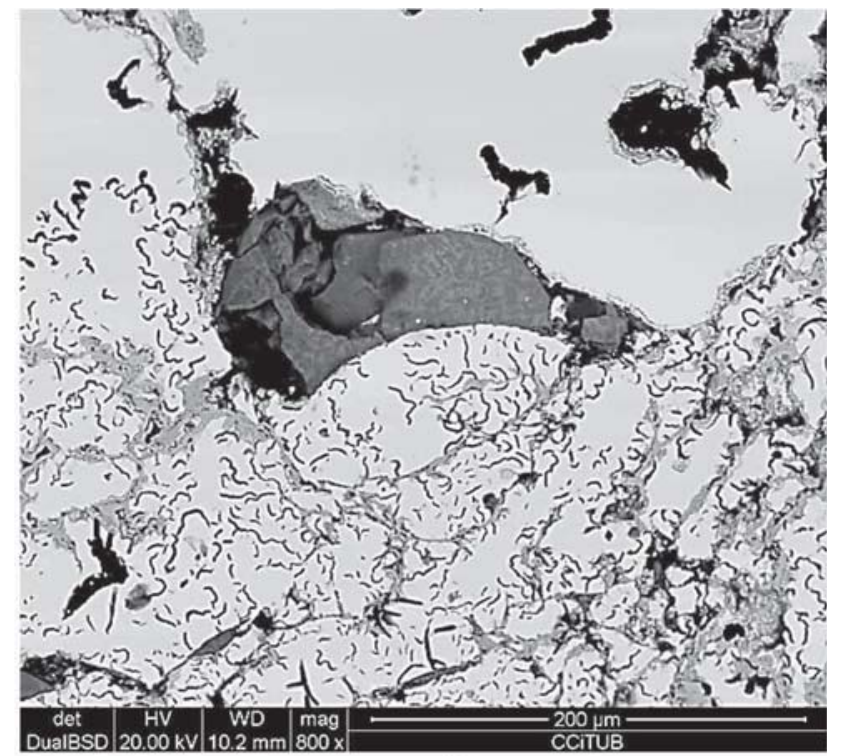

(b)

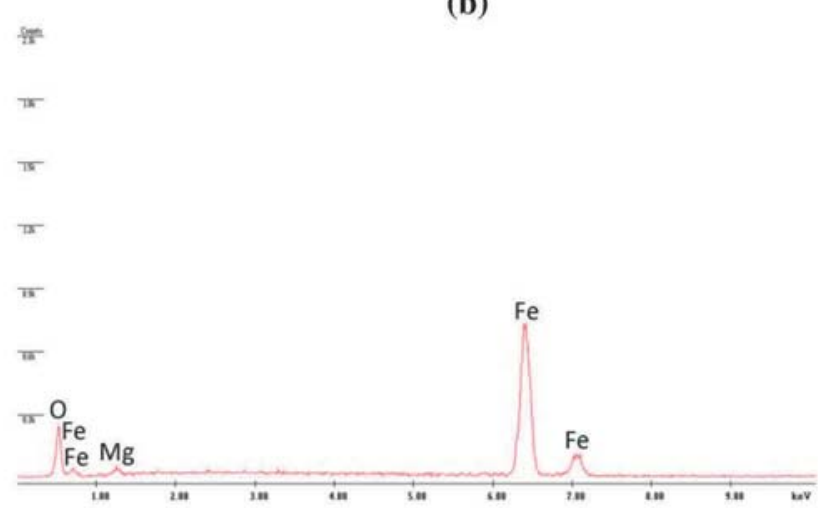

(d)

Figure 13. SEM micrographs of a dross inclusion: (a) general view, stringers marked by arrows and (b) detail of a slag particle. Below EDS microanalyses (c) of the slag particles and (d) of the surrounding dark stringers.

external areas of the pressure pour device are composed by spinel and magnesium-bearing silicates as main constituents and by periclase and wustite $(\mathrm{FeO})$ as minor ones. This clear discrepancy in composition has been assigned to the different oxidizing level which is comparatively low in the internal cavity. Thus, composition of adhered slag is strongly affected by the air exposition of melt.

5. Two types of slag inclusions can be found in the SG cast iron parts, the bulk-shaped particles and the stringers, and the last commonly known as "dross inclusions." Although both types can be characterized by SEM-EDS microanalysis to obtain magnesium, silicon and oxygen as the most important elements, additional peaks of iron, calcium and/or rare earth elements have been detected on the bulk-shaped inclusions that were not recorded in dross defects. Thus, the former inclusions show the elements that were also found on slag samples collected in the pressure pour and it can be assumed that their formation occurred in the pouring furnace before pouring the molds.

6. The sporadic presence of sand grains and inoculant rests associated with the bulk-shaped slag inclusions seems to support the assumption about the origin of these inclusions in the pressure pour furnace. In case of dross inclusions, oxidation of magnesium and silicon due to turbulences that occur during pouring processes seems to be the cause of their formation.

7. A comparative analysis of data obtained from all XRD studies carried out in the present work indicates that the amount of amorphous phases present in the samples increases as the slag formation rate does, as the silicon content becomes high and as cooling of slag becomes rapid. 


\begin{tabular}{|l|lll|}
\hline Journal : Large 40962 & Dispatch : 9-2-2016 & Pages : 17 \\
Article No. : 26 & $\square$ LE & $\square$ TYPESET \\
MS Code : IJMC-D-15-00004 & $\cup_{\text {CP }}$ & $\checkmark$ DISK \\
\hline
\end{tabular}

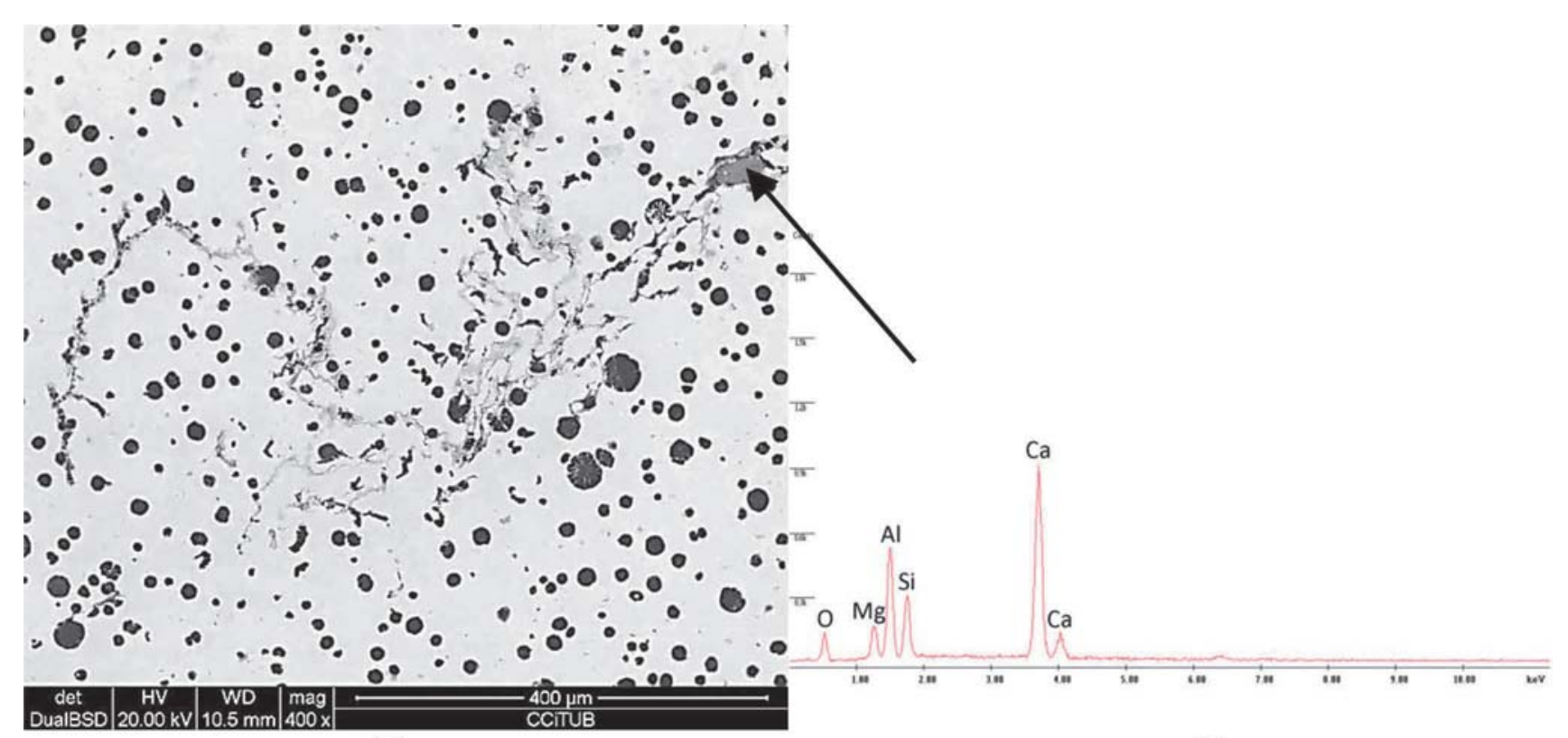

(a)

(b)

Figure 14. (a) SEM micrograph of a dross inclusion with a bulk-shaped particle (marked by an arrow) and (b) EDS microanalysis of this particle.

\section{Acknowledgments}

This work has been financially supported by Fundería Condals S.A foundry and by Catalan Government by awarding the scholarship from AGAUR for the Industrial $\mathrm{PhD}$. The authors would like to acknowledge Centres científics i tecnològics (CCiT) from the Universitat de Barcelona for the collaboration in all the analysis.

\section{REFERENCES}

1. R.W. Heine, C.R. Loper, Dross formation in the processing of ductile cast iron. Trans. Am. Foundrymen's Soc. 74, 274-280 (1966)

2. A. Loizaga, J. Sertucha, R. Suárez, Influencia de los tratamientos realizados con diferentes ferroaleaciones de magnesio en la evolución de la calidad metalúrgica y los procesos de solidificación de las fundiciones esferoidales. Rev. Metal. 44(5), 432-446 (2008)

3. P. Trojan, P. Cuichelaar, W. Bargeron, R. Flinn, An intensive investigation of dross in nodular cast iron. Trans. Am. Foundrymen's Soc. 76, 323-333 (1968)
4. D.R. Askeland, P.K. Trojan, R.A. Flinn, Dross forming 758 reactions in the system $\mathrm{Mg}-\mathrm{Si}-\mathrm{O}$ in ductile iron. AFS Trans. 80, 349-358 (1972)

5. M.C. Latona, H.W. Kwon, J.F. Wallace, J.D. Voss, 761 Factors influencing dross formation in ductile iron $\quad 762$ castings. Trans. Am. Foundrymen's Soc. 131, 881-906 763 (1984)

6. M. Gagné, M.-P. Paquin, P.-M. Cabanne, Dross in 765 ductile iron: source, formation and explanation. FTJ 766 276-280 (2009)

7. P.-M. Cabanne, C. Labrecque, G. Murratore, H. 768 Roedter, Production of heavy and thick ductile iron $\quad 769$ castings (process review and potential defects). Indian 770 Foundry J. 56(2) (2010)

8. I. Santos, J. Nieves, P.G. Bringas, A. Zabala, J. 772 Sertucha, Supervised learning classification for dross $\quad 773$ prediction in ductile iron casting production, in $2013 \quad 774$ IEEE 8th Conference on Industrial Electronics and 775 Applications (ICIEA) ${ }_{n o}$

\section{5}

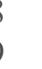
(1) , . 
Journal : 40962

Article : 26

黑 Springer

the language of science

\section{Author Query Form}

\section{Please ensure you fill out your response to the queries raised below and return this form along with your corrections}

\section{Dear Author}

During the process of typesetting your article, the following queries have arisen. Please check your typeset proof carefully against the queries listed below and mark the necessary changes either directly on the proof/online grid or in the 'Author's response' area provided below

\begin{tabular}{|l|l|l|}
\hline Query & Details Required & Author's Response \\
\hline AQ1 & $\begin{array}{l}\text { Figures 2, 4, 6, 7, 9,10-14 are poor in quality as its labels are not readable. Please supply a new version of } \\
\text { the said figure with legible labels preferably in .eps, .tiff or .jpeg format with 600 dpi resolution. }\end{array}$ & \\
\hline AQ2 & Please confirm the corresponding affiliation is correctly identified and amend if necessary. & \\
\hline AQ3 & Please check the edit made in the article title. & \\
\hline AQ4 & Please check the spelling of the term 'nodularization'. & \\
\hline AQ5 & Please check the clarity of the sentence 'The explanation for...coincident XRD spectra'. & \\
\hline AQ6 & Please check the clarity of the sentence 'Dark gray particles...on the micrograph)'. & \\
\hline AQ7 & Please update Ref. [6] with volume number. & \\
\hline AQ8 & Please update Ref. [7] with page range. & \\
\hline
\end{tabular}

